\title{
OPPORTUNITY TO BE HEARD IN LICENSE ISSUANCE
}

Clark Byse $\dot{\mathrm{i}}$

The objective of a licensing system is to prevent anti-social conduct from occurring by restricting participation in the licensed activity to qualified personnel. If the process of selecting licensees is to be discharged intelligently and if those seeking to engage in the licensed business are to be treated fairly, the licensing agency must be fully informed concerning applicants' qualifications.

One procedure for acquiring and verifying data needed in the license issuance process is the administrative counterpart of a judicial trial, herein called a "hearing." The essential characteristics of a hearing are receipt of testimony (generally under oath), opportunity for cross-examination, transeription of the testimony in a record, and decision on the basis of the record. Unless otherwise indicated, the terms "hearing" and "opportunity to be heard" as used in this paper refer to that type of procedure. Other procedures for acquiring or verifying information include a public hearing similar to that employed by legislative committees, application forms, tests, examinations, conferences, communications from the applicant or third persons, and investigations by the staff of the licensing agency.

The agencies of government sharing the responsibility for choosing from among these procedures are the legislative, the administrative, and the judicial. Their choices will depend upon a variety of factors including: the efficacy of the procedure, in light of the character of the issue involved, to elicit and verify the needed data; the hardship to the members of the class of applicants in question of denial of the license; the value of a hearing as a deterrence to arbitrary or corrupt action; the character and personnel of the licensing agency; the existence of other safeguards; the expense and delay involved in granting hearings; fairness to the parties; and the importance to society not only that officials act justly but also that they appear to act justly.

This paper is the result of an effort to ascertain how the problem has been handled in a single field of state regulation, the retail sale of alcoholic beverages. Other licensed activities might have served as

†.E., 1935, Wisconsin State College; LL. B., 1938, University of Wisconsin; LL. M., 1939, Columbia University; Professor of Law, University of Pennsylvania Law School. 
well for the purpose of the study, which is the intensive consideration of the interrelationship of legislative, administrative, and judicial processes in a limited sphere of government regulation. Alcoholic beverage regulation was selected because courts, recognizing the social problems attendant on the sale of alcoholic beverages, traditionally have accorded its regulation a special status, permitting greater freedom in this field than in many others. Here, then, more than elsewhere, legislators and administrators should be concerned more with the wisdom than with the constitutionality of their action. Also, all of the existing alcoholic beverage control acts have been adopted within the last twenty years, a period roughly coinciding with nearly two decades of increasing concern with the practices and procedures of administrative agencies. Legislative and administrative action in this field thus should have been influenced by the new emphasis on fair administrative procedure; and that action should have been relatively unhampered by the inertia which understandably limits change in established practices and procedures. Finally, widely varying procedural patterns have developed in the various states. While this diversity makes the story somewhat complex, it supplies a valuable opportunity to compare the operation of different systems. The states here admirably provide the laboratories of experiment which, as Mr. Justice Brandeis well said, constitute one of the special virtues of a federal system of government. ${ }^{1}$

Since in administrative law, probably more than in other branches of public law, "we must travel outside the covers of law books to understand law," ${ }^{2}$ a questionnaire was sent to each of the state alcoholic beverage control agencies participating in the issuance of retail licenses. $^{3}$ Although a few agencies failed to reply and the answers of others were fragmentary, the information furnished by the remaining agencies is sufficiently representative and detailed to permit intelligent discussion and appraisal. ${ }^{4}$

1. Dissent in New State Ice Co. v. Liebman, 285 U.S. 262, 311 (1932). (1927).

2. Frankfurter, The Task of Administrative Law, 75 U. of PA. L. Rev. 614, 620

3. The questionnaire, which is reproduced in the Appendix, infra, was mailed to the chairman or director of each of the forty-one state alcoholic beverage control agencies participating in the issuance of retail licenses. The seven states excluded from this study are Utah, which issues no retail licenses of the type covered by the study (see footnote 6 infra), Mississippi and Oklahoma, which follow a policy of prohibition, and Nevada, Maryland, Wisconsin and Wyoming, in which license issuance is basically a responsibility of local authorities.

4. Replies were received from thirty-two of the forty-one agencies. Those not replying were Alabama, Arizona, Colorado, Idaho, Iowa, Kentucky, Missouri, Tennessee, and Texas. As might be expected, there were wide variations in the quality of the replies. At one extreme was the action of Louisiana and South Dakota in merely forwarding copies of the control law and the rules and regulations 
There is general legislative utilization of the licensing device as a control mechanism in post-repeal alcoholic beverage legislation. ${ }^{5}$ There is no similar unanimity in legislative provisions or administrative policies concerning an opportunity to be heard in the process of issuing retail alcoholic beverage licenses. Instead, the following procedures are utilized: (1) no hearing in the issuance process; (2) hearing on all applications; (3) hearing in event the agency initially refuses the application and the applicant thereafter requests a hearing. There are also statutory and administrative provisions granting interested third persons an opportunity to be heard.

Although these groupings are not necessarily exhaustive or mutually exclusive, ${ }^{6}$ they are generally descriptive of the more widely adopted solutions to the problem and are employed as the basis for the discussion which follows.

issued thereunder; at the other, were unusually helpful and detailed replies from several agencies.

As Professor E. W. Patterson noted in connection with a more ambitious use of the questionnaire method, "One must get the 'facts' as far as one can. One must give not an armchair guess, but an informed guess. That is the most that I can claim for this study. "PATterson, THE INSURANCE COMmMssioner in the United States 548 (i927).

5. Two states follow the policy of prohibition. Twenty-nine regulate the liquor traffic by licensing those who engage in it. Seventeen, known as monopoly states, operate state-owned stores for the sale of alcoholic beverages; in most of these enumerated classes of retail outlets also are licensed. For details see CHILDS, Making Repeal Work cc. IV, VI (1947); The Jornt Committee of the States to Study Alcoholic Beverage Laws, Alcoholic Beverage Control 23-24 (1950).

6. A few states employ procedures not embraced by the above categories. E.g., New York, in which local alcoholic beverage control boards make recommendations to the State Liquor Authority concerning issuance or refusal of retail licenses. In event the local board recommends disapproval of the application, the Authority is required to give the applicant a hearing. N.Y. Alcomolic Beverage Control LaW $\$ \S 43,54,63$. But if the local board recommends issuance, the Authority may refuse the license without a hearing. Stachura v. O'Connell, 271 App. Div. 162, 63 N.Y.S.2d 611 (3d Dep't 1946). In Florida the Director of the Alcoholic Beverage Department is required to accord applicant a hearing in event of initial refusal; if after hearing the Director refuses issuance, applicant may secure review by the "governor who shall order the application to be granted or denied as justice shall require." FIA. STAT. \$ 561.19 (1949).

Or a single state may utilize more than one of the procedures. E.g., Pennsylvania, which provides both an administrative hearing in event of initial refusal and a court hearing in de novo judicial review proceedings. PA. Stat. ANN., tit. 47 \$ 4-464 (Purdon Supp. 1951). The Kansas Director of Alcoholic Beverage Control is required to give a hearing to all applicants for retail licenses. In event the Director refuses the application, the applicant may appeal to and be heard by the Alcoholic Beverage Control Board of Review. Kan. Gen. Stat. ANN. \$§41-318, 41-321 (Corrick 1949).

Or one control act may provide for different procedures for different classes of retail licenses. E.g., Texas, which requires a hearing on all applications for beer licenses, but provides that application for liquor licenses may be granted or denied "with or without a hearing." TEX. PEN. CoDE ANN. arts. 667-6, 666-11 (Supp. 1951). Maine requires approval of, and a public hearing before, municipal officials with respect to applications for on-premise retail liquor licenses, and in event those officials refuse approval, the applicant may appeal to the state agency which gives a hearing thereon. But when the state agency passes on applications for off-premise 


\section{Denial of Hearing}

There appears to be no statute which explicitly prohibits a hearing in the process of issuing retail alcoholic beverage licenses. But approximately two score alcoholic beverage control acts, authorizing license issuance, are silent about the necessity of a hearing. ${ }^{\text {? }}$ Agencies administering these provisions perforce have been faced with the administrative problem of determining whether to grant or deny hearings in issuing retail licenses. ${ }^{8}$ The questionnaire replies indicate that a few agencies have resolved the problem by denying hearings in the issuance process. ${ }^{9}$

retail beer licenses, no hearings are required. ME. REv. STAT. c. 57, $\S 22,23,40$ (1944).

Although this paper deals with retail licenses, because as pointed out in HARRISON AND LAINE, AFTER REPEAL 52 (2d ed. 1936) that "is the most important field of licensing activity," no attempt has been made to include all the state provisions concerning issuance of train, boat, airplane, or other special types of retail licenses.

7. Provisions of alcoholic beverage control acts containing no explicit directions concerning the grant or denial of hearings in the issuance of retail licenses are the following: Ala. Code AnN. tit. 29, \$15 (cf. \$ 18) (1940) ; Ariz. Code Ann. \$ $72-$ 108 (a) (cf. $\$ 72-103$ (b) (5)) (Supp. 1951); Colo. Stat. ANN. c. 89, \$\$21, 22 (1935); Ga. Laws Extra Sess. 1937-38, No. 297, § 8(b), p. 108-9; IDAmo Code ANN. \$\$ 23-903, 23-907, 23-933 (1948) ; IowA CoDE \$124.5 (1950) (see Att'y Gen. Op., July 3, 1951, CCH Lio. Cont. L. Rep. (Iowa) par. 9001 (1951)); ME. Rev. Stat. c. 57, $\$ 23,40$ (1944); Mich. Comp. Laws $\$ 436.17$ (1948); Mrnn. Stat. $\$ 340.11$ (1949); Mo. Rev. STat. \$\$ 311.210, 311.610 (1949); Mont. REv. Codes Ann. tit. 4, \$4-327 (1947), \$ 4-342 (Supp. 1951) ; Neb. Rev. Stat. \$ 53-137 (1943); N.H. Rev. Laws c. $170, \$ \$ 59,60,70$ (1942); N.M. STat. Ann. $\$ 61-516$ (Supp. 1951) ; N.D. Laws 1951, c. 101, § 1, N.D. REv. CoDE \$ 5-0503 (Supp. 1947); Ore. Laws 1949 , c. $445, \S \S 2$, 12, Ore. Laws 1951, c. $469, \S 1$; TEx. PEN. Cope ANN. art. 666-11 (Supp. 1951); Vr. Rev. STAT. $\$ \$ 6137,6155$ (1947); WAsH. Rev. Code $\$ 66.24 .090$ (1952); W. VA. Code ANN. \$999(42) (Supp. 1951).

8. Of the twenty agencies administering alcoholic beverage control acts containing no explicit directions concerning grant or denial of hearings in the issuance of certain types of retail licenses, see note 7 supra, thirteen responded to the questionnaire. Three indicated no hearings were given in the issuance process; see note 9 infra. Six indicated that hearings are given in event of initial refusal of the application and applicant thereafter requests a hearing; see note 43 infra. Three replies were so ambiguous or unresponsive as not to permit classification. Washington stated that hearings are given "occasionally" in event of initial refusal of the application and applicant thereafter requests a hearing. The policy of the New York State Liquor Authority (see note 6 supra) is set forth in the following statement: "As a matter of law, an applicant who, within ten days after notice by local ABC board that his application has been recommended for disapproval, requests in writing a hearing thereon is entitled to such hearing before the Liquor Authority. As a matter of policy, the Liquor Authority also holds hearings on all applications for license where (a) premises for which license is sought are not currently licensed; (b) protests against favorable action on the application have been filed either with the Local Board or with the Liquor Authority; (c) a change in type of license is sought (as, for example, from a license authorizing sale of beer to a license authorizing sale of liquor and wine as well); and (d) in all other instances where in the opinion of the Licensing Board there is reason to set up a hearing." The Jornt Complitee of the States to Study Alcoholic Beverage Laws, Alcoholic Beverage Control 17-18 (1950). See also par. 14 of Rule 1 of N.Y. Liq. Auth. Regulations providing for "investigative interviews."

9. Maine, North Dakota, West Virginia. See also note 18 infra. 
One agency's explanation for this denial is that since the statute did not provide for a hearing in the issuance process, the agency has no "power" to grant a hearing. This reasoning is somewhat less than satisfactory. There is a much criticized ${ }^{10}$ minority doctrine stemming from a dictum in Stuart v. Palmer ${ }^{11}$ to the effect that if due process requires a hearing, the fact that a hearing actually was given is immaterial; the statute under which the agency is operating must specifically require a hearing, and if it does not, the statute is unconstitutional. Conceivably, a legislature in a jurisdiction adhering to this doctrine might become so sensitive to the Stuart v. Palmer rule that in each instance it desired hearings it would specifically require them; in such a state there might be basis for concluding that failure to require a hearing reflected a legislative decision that a hearing should not be given. Except possibly in New York, it is doubtful that any legislature follows such careful drafting procedures. ${ }^{12}$ The failure specifically to require a hearing should be construed to mean just that: the licensing agency is not required to give a hearing. In the absence of some specific indication of a legislative purpose to prohibit hearings, the sound approach for the administrator in the first instance and the court in the second is that the legislative delegation of power to make determinations carries with it the power to use every reasonable procedure for reaching an intelligent decision. ${ }^{13}$ Whether or not a hearing in any particular instance will constitute reasonable procedure will of course depend upon a variety of factors. The argument here is not that a hearing necessarily should be given. The point is that a hearing should not be refused because of an erroneous conception of the effect of a legislative failure expressly to provide for a hearing.

Another reason given in the questionnaire replies for the administrative decision to deny hearings in the issuance process is that hearings are unnecessary because of the thorough investigation conducted by the agency. An investigation is a useful procedure for acquiring and verifying information. In some instances, it may be superior to a hearing procedure. For example, common requirements concerning the proposed establishment are that it shall be located a specified distance from schools, churches, and other public institutions, that the premises shall be open to full view from the outside or the

10. Gellahorn, Administrative Law Cases and Comments 357 (2d ed. 1947); Cooper, Administrative Agenctes and the Courts 84 (1951).

11. 74 N.Y. 183, 188 (1878).

12. See Note, The Necessity of a Notice and Hearing in Administrative Determinations, 80 U. of PA. L. REv. 96, 99 (1931).

13. For a judicial declaration to this effect in a slightly different context, see State ex rel. Milwaukee Medical College v. Chittenden, 127 Wis. 468, 516, 107 N.W. 500, 516 (1906). 
entrance, and, if it be a restaurant, that it have specified dimensions and seating capacity. ${ }^{14}$ The sensible way to ascertain whether requirements of this character have been met is to send an inspector to the premises to make the necessary determinations and report to the licensing agency. The same determinations could be made by putting the inspector on the stand, receiving his testimony under oath, permitting cross-examination, transcribing the testimony and examination in a record, and deciding on the basis of the record so compiled. Such a procedure is obviously more time-consuming and costly than the simple, direct, informal procedure of inspection and report. There is no discernible advantage to be gained from a hearing, because even if a hearing were provided, the official inspector's testimony would, in all probability, be the decisive factor in the proceeding. ${ }^{15}$ Protection against the unlikely possibility of a mistake by the inspector "can be afforded by a right to re-examination or reinspection by another and more experienced inspector, far more than by any right to a formal hearing before an official who must merely listen to testimony." ${ }^{16}$

In situations of this type, it is sensible to utilize an investigatory rather than a hearing technique. But in other circumstances a hearing will be a better instrument for reaching decisions. Where the issue relates to intangibles like present reputation or to past facts which must be reconstructed through narration, the methods of a trialprincipally cross-examination-will be a superior means for discovering intentional falsehood and correcting unwarranted inferences. Since the objective of the procedure employed is the expeditious enlightenment of the agency, it is unfortunate that any agency should fail to utilize the hearing device in those situations where it is the most appropriate means for eliciting and verifying the needed data.

A third reason for refusing hearings in the issuance process, as reflected in replies to the questionnaire, is that the hearings are unnecessary in light of the opportunities afforded the applicant to supply information and meet objections in what may be called the informal administrative process-filling in application forms, interviews, conferences, letters, etc. Informal administrative procedures play an important role in license issuance. License applicants are not interested in administrative or judicial litigation. Their objective and the objective of their counsel is to secure administrative approval of the ap-

14. The Joint Committee of the States to Study Alcoholic Beverage Laws, Alcoholic Beverage Control 103 (1950); Childs, Making Repeal Work 112 (1947).

15. Gelliorn, Federal Administrative Proceedings 65 (1941).

16. Rep. Arr'y Gen. Conm. Ad. Proc. 38 (1941). See also Gellhorn, op. cit. supra note 15 , at $64-65$. 
plication. Rather than risk an adverse administrative decision and its affirmance on judicial review, the applicant often will make the adjustments suggested by the agency's staff. ${ }^{17}$ This obvious fact is, of course, recognized by the licensing agencies. Accordingly, they usually notify the applicant of defects in his application and of staff objections to issuance. Only in the event of failure to make the changes requested by the staff will a hearing be necessary.

A most illuminating description of informal procedures enabling applicants to correct deficiencies in applications and to meet objections to issuance raised by the agency's staff or third persons is that of the Virginia Alcoholic Control Board. The Board's statement so graphically portrays the workings of the informal administrative process in license issuance that it is set forth substantially in full:

"Every effort, from telephone calls to detailed letters, may be made to inform an applicant as to the defects in his application or of objections to issuance of a license to him. Except for police information of a confidential nature, and we have very little of this sort of thing, an applicant has full access to his application file. To be specific, if there is a defect in an application, the License Director informs the applicant of the defect and offers suggestions as to how it may be corrected. If there are objections to issuance of a license other than a defect in the application, the applicant is informed that there are objections and that an opportunity to be heard in the field will be afforded him in the near future. The applicant receives a reasonably detailed statement of the objections and their sources in a more or less formal notice which is sent out approximately two weeks prior to the hearing.

"In addition, the Board affords both applicants and protestants every opportunity within reason to organize their evidence and to present it fully and completely. If a person applies for a particular type of license, and it appears to the Board as a result of an Inspector's investigation that the place in question is not qualified for certain of the privileges applied for, a letter is written to the applicant apprising him of the Board's position and he is asked if he will accept a license carrying only the privileges which the Board would approve without question, or whether he desires a hearing relative to the questionable privileges. Another example might be where a hearing is held and, during the hearing, the applicant discovers that certain changes in the physical arrangement at his place of business would better qualify him for a license. In such a case, he might be given a considerable length of time in which to make the changes before further consideration would be given to his application, or the license might be granted on condition that he would make the contemplated changes

17. Cooper, Administrative Agencies and the Courts 76 (1951). 
in the physical arrangement of his establishment. The Board is always willing to advise an applicant why his establishment appears to be unsuitable, but in no case does the Board dictate to an applicant what changes are to be made. Our Inspectors are kept fully advised as to current policies of the Board pertaining to the issuance of licenses and they are always available to answer any question presented to them. Even if a person has not made formal application to the Board for a license, we are always willing to offer advice as to what position the Board has taken in similar cases and to offer suggestions as to what might be done to facilitate action should an application be filed. On the other hand, we are always willing to do the same thing for persons who object to the issuance of a license. In other words, we try to give both sides the benefit of our experience but no definite stand is taken until after a hearing."

Although other questionnaire replies to the item calling for information concerning informal procedures are not so complete as the Virginia statement, they contain ample evidence of the widespread utilization of those procedures in the issuance of retail alcoholic beverage licenses.

Investigations and informal procedures are vitally important instruments and their intelligent use often will make a hearing unnecessary. But neither investigations nor informal procedures should be regarded as a substitute for a hearing in all instances. Whenever the matter cannot be adjusted informally and there remains an issue which can best be explored by trial methods, a hearing should be granted. The lesson is clear. Each of the procedures has particular values. None of the procedures should be completely rejected. Selection among the procedures should be based upon a practical analysis of which instrumentality is best suited to elicit and verify the needed information.

License applicants who have appealed to the courts for reversal of the administrative decision to deny hearings in the issuance process have been notably unsuccessful. ${ }^{18}$ In rejecting the contention that a hearing should be given, the courts have emphasized the circumstance that although the statute did not provide for a hearing in issuance cases, it expressly required a hearing in revocation proceedings. "The inference is that no hearing is required upon such an application and that the control commissioners may act upon the basis of any knowl-

18. State ex rel. Renner v. Noel, 346 Mo. 286, 140 S.W.2d 57 (1940); Usdane v. Bruckman, 30 N.Y.S.2d 396 (Sup. Ct. 1941); State ex rel. Camper v. Pollard, 189 Tenn. 86, 222 S.W.2d 374 (1949) ; State ex rel. Billado v. Control Commissioners, 114 Vt. 350,45 A.2d 430 (1946); cf. Yarbrough v. Montoya, 54 N.M. 91, 214 P.2d 769 (1950); Olds v. Kirkpatrick, 183 Ore. 105, 191 P.2d 641 (1948). Contra: Martin v. Board of Supervisors, 135 Cal. App. 96, 26 P.2d 843 (1933). 
edge or information available to them, so long as their action is not arbitrary or capricious . . . ."19

This is a plausible but not necessarily conclusive argument. The issue in suspension and revocation cases usually is whether the licensee has violated a statute or regulation. The testimonial, adversary process of a hearing is uniquely suited to ascertaining facts concerning alleged past violations. Moreover, suspension or revocation of a license has an immediate and direct impact on the licensee; unless the order is stayed, the licensee is out of business. Different considerations are involved in license issuance. Refusal of permission to engage in the licensed business may involve, a hardship but not nearly to the same degree as expulsion from one's existing means of livelihood. A license application upon its face may disclose facts warranting summary denial. Or facts conceded by the applicant in discussions or correspondence with the agency may justify denial without a hearing. In situations such as these a hearing would be wasteful: there is no need to prove that which is conceded or admitted. But when license issuance or refusal depends upon controverted facts relating to past conduct, an adversary hearing is an unusually effective method for resolving the controversy. In situations of that character, there is no reason to infer a legislative purpose that hearings be denied. Rather, it is logical to conclude that the legislature, recognizing the differences between license issuance and license suspension or revocation, determined to treat them differently, and that the purpose of the legislature in not requiring a hearing in all issuance cases was to avoid burdening the administrative agency with the task of conducting hearings in instances in which a hearing would serve no useful purpose; but that where a hearing would be the most effective method for acquiring and verifying needed information, a hearing should be given. ${ }^{20}$

It might be argued that this reading of the statute overlooks the fact that a legislature desiring to make the distinctions suggested would have given some specific indication of that desire, and that in the absence of explicit legislative directions, or constitutional limitations, the procedure to be followed by an administrative agency is generally determined by the agency, not by a court. The first argument loses much of its potency when it is remembered that the alcoholic beverage control acts under consideration neither require nor prohibit a hearing in the issuance process. Therefore it may be inferred that the legis-

19. State e.t rel. Billado v. Control Commissioners, 114 Vt. 350, 354, 45 A.2d 430,432 (1946).

20. See Smith v. Foster, 15 F.2d 115 (S.D.N.Y. 1926); Perpente v. Moss, 293 N.Y. 325, 56 N.E.2d 726 (1944) ; Benjamin, Adirtnistrattve AdJudication in the State of NEW York 102 (1942). 
lature either did not consider the problem or intentionally left it for administrative or judicial solution. In either event, the administrative agency or the court, in determining whether a hearing should be given in a particular issuance proceeding, most assuredly should consider the consequences of the proceeding, the nature of the question, the character of the evidence, the data set forth in the application form, and the admissions of the applicant. The really significant issue thus is not whether the statute should be read with discrimination, taking these factors into consideration, but rather, whose reading-court or agency-shall be determinative.

There is much to be said in support of the second argument that this is an administrative and not a judicial responsibility. But administrative interpretation of a statute always is subject to judicial review, the only question being what is, or should be, the scope of review. State courts have shown little disposition to defer to administrative interpretation of statutes. Assuming, however, that state courts would or should accept the administrative interpretation if it is "reasonable," whether or not it is "correct," it does not follow that the decisions under discussion which affirmed the administrative refusal to give a hearing in issuance proceedings were decided correctly.

Judicial deference to administrative determinations rests primarily upon the agency's presumed superior knowledge and expertness in the area of regulation. This does not mean that everything an agency does is either reasonable or correct. It means only that when the agency's presumed superior knowledge and expertness have been brought to bear, a court should not interfere except to correct flagrant errors. Before a reviewing court defers to an administrative decision to deny hearings in issuance proceedings, it should satisfy itself that the decision is based upon full (expert) consideration of all relevant factors. If the agency is unable to convince the court that its determination is based upon its expert understanding of the considerations involved, the court should refuse to accept the determination. The court should, instead, return the matter to the agency for its informed, expert judgment. ${ }^{21}$

Under this analysis, the judicial decisions affirming the administrative determination to refuse a hearing in the issuance process were incorrectly decided, for in none of them does it appear that the administrative determination to deny hearings was based upon full consideration of the factors involved.

Administrative denial of a hearing by a local licensing agency appointed by the local legislative governing body has also been upheld on

21. Cf. Jacob Siegel Co. v. FTC, 327 U.S. 608 (1946). 
the theory that the governing body, acting through its appointed licensing agency, exercises a power "in the nature of local option" to decide whether licenses should be issued. ${ }^{22}$ The argument in support of this theory is that the local governing body in effect determines the policies of the licensing agency, because if the actions of the licensing agency do not correctly reflect local sentiment, the governing body may remove the members of the agency and appoint in their places officials who will represent the wishes of the locality.

This theory involves considerable stretching of the principle of local option. Under local option legislation, both before prohibition and after repeal, the voters of local units are empowered to decide whether the sale of alcoholic beverages should be prohibited. ${ }^{23}$. Local option thus is an instrument which enables the electors of a community to determine the basic policy of whether to prohibit or permit alcoholic beverage sales in the community. Legislation giving local governing bodies power to decide the issue constitutes only a slight extension of the theory of local option, for the basic policy decision, although not made by the voters, is made by their elected representatives. To permit that policy to be made by an appointive agency, even though the policy may be reversed by removing agency members and appointment of new officials, involves a further, and undue, extension of local option theory. More important, local option is a device for permitting local sentiment to determine the general question of sale or no-sale of alcoholic beverages. It is not an appropriate instrument for determining whether a particular applicant shall be granted or refused a license to engage in the business.

A third reason given in support of judicial refusal to reverse the administrative decision to deny hearings to license applicants is "that if it had been the intention of the Legislature that each applicant have a formal hearing . . . the act would have said so, just as it does, for instance in Code section 6236.27 [of Tennessee], with reference to the refusal of the insurance commissioner to grant an application for a license to write insurance." 24 The leading treatise on statutory construction, warning against uncritical acceptance of the principle that statutes in pari materia should be construed together, describes as "fictitious" the proposition that whenever the legislature enacts a

22. State ex rel. Camper v. Pollard, 189 Tenn. 86, 222 S.W.2d 374 (1949).

23. Osborn, Liquor Statutes in the United States, 2 HARv. L. REv. 125, 128-130 (1888) ; FOSDICK AND SCOTT, TOWARD LiQUOR CONTROL $52-55$ (1933); HarRISON AND LAINE, AfTer Repeal 70-73 (2d ed. 1936). (1949).

24. State ex rel. Camper v. Pollard, 189 Tenn. 86, 91, 222 S.W.2d 374, 376-377 
statute it has in mind all prior acts relating to the same subject matter. $^{25}$ Even less realistic is the suggestion that the legislative purpose of a statute is to be gauged by legislative action in passing another statute dealing with an entirely different subject matter. Different sponsors, different draftsmen, different committees, different legislative sessions, rather than deliberate legislative choice account for the diversity in language. This is particularly true in this case because Code section 6236.27, dealing with licensing insurance agents, was enacted in $1935,{ }^{26}$ and the alcoholic beverage control statute was enacted in $1933 .{ }^{27}$ It is startling, to say the least, to learn that the purpose of the legislature in 1933 is to be gauged by its action two years later in passing a statute dealing with an entirely different subject matter.

In the uncommon case where a court has reversed the administrative determination to deny a hearing in the issuance process, the ground has been that a licensing agency charged with the responsibility of issuing licenses on stated terms and conditions thereby becomes a "quasijudicial" body, and that in such circumstances "the law contemplates a fair and impartial hearing. . . ." 28 The opinion does not make clear whether the "law" referred to is the statute involved or the common law of judicial supervision of administrative agencies. In the case, a county board of supervisors denied a license on the basis of ex parte statements by the district attorney and the sheriff which indicated the unfitness of applicant and the unsuitable surroundings of her restaurant. The licensing agency should, of course, consider the opinion of, and information supplied by, county officials. But at the very minimum the applicant should be afforded the opportunity to explain or rebut that data.

Confined to its facts, the decision, which directed the board to grant applicant a hearing, is a refreshing departure from the otherwise apparently unanimous judicial approval of administrative refusal of hearings. It might be argued that instead of directing the board to grant a hearing, the court should have remanded the cause to the board with directions that it give full consideration to the advisability of granting a hearing. ${ }^{29}$ However, as between the usual acquiescence in the administrative determination to refuse a hearing and the action

25. 2 Sutherdand, Statutory Construction 545 (3d ed., Horack, 1943).

26. Tenn. Acts 1935 , c. $157, \S 1(\mathrm{f})$.

27. Tenn. Acts 1933 , c. $69, \S 10$.

28. Martin v. Board of Supervisors, 135 Cal. App. 96, 102, 26 P.2d 843, 845 (1933). The case is discussed in Sears, Licenses and Procedural Due Process 7, 18, in Brochure on Administrattve Law (A.B.A. Sect. Jud. Admin. 1943).

29. See text at note 21 supra. 
taken by the court, the latter is clearly preferable, and particularly so when, as here, the licensing agency is the local legislative body. ${ }^{30}$

Only rarely has an applicant refused a hearing by the licensing agency argued that due process of law requires an opportunity to be heard before denial of his application. When he has done so, his argument has been rejected on the ground that the sale of alcoholic beverages is a "privilege," not a "right." 31 It is difficult to resist the urge to fire both barrels at such a sitting duck as the privilege-right dichotomy. But others have so blasted this "particularly arid and unhelpful conceptualism" 32 that an additional volley would be a waste of ammunition. Suffice it to note that "privilege" is simply a label which expresses a conclusion reached on other grounds; it tells us nothing about the reasons, if any, for the conclusion.

Despite the patent unhelpfulness of the privilege-right reasoning in reaching the result, it is difficult to take issue with the conclusion that due process of law does not require a hearing before administrative denial of an application for a license to sell alcoholic beverages. Although there are occasional cases, both before prohibition and after repeal, in which courts have held that licensing agencies must provide an opportunity to be heard before refusal of the application, the decisions are not based on due process of law requirements. ${ }^{33}$ Whenever the constitutional issue has been presented, both before prohibition and after repeal, the holding has been that due process of law does not require a hearing before administrative refusal of an application for a retail alcoholic beverage license. ${ }^{34}$ There are, of course, instances in license application cases in which a hearing would be eminently desirable-e.g., when the issue is the applicant's "moral character" or "reputation." 34a But the lack of any case authority in the long

30. Dickinson, Administratrve Justice and the Suprenacy of the Law 256 (1927) : ". . . it is in cases of discretionary action by petty officers that there is the greatest danger of injustice to individuals from governmental oppression."

31. State ex rel. Billado v. Control Commissioners, 114 Vt. 350,45 A.2d 430 (1946).

32. Gellhorn, Administrative Law Cases and Comments 273 (2d ed. 1947); Datts, Administrative Law 251 (1951); CoOper, Administrative Agencies and THE COURTS 78-79 (1951).

33. Reed v. Collins, 5 Cal. App. 494, 90 Pac. 973 (1907) (ordinance requiring "due consideration" of the application means that the licensing agency should hear evidence); Martin v. Board of Supervisors, 135 Cal. App. 96, 26 P.2d 843 (1933) (discussed in text at note 28, supra). See also The Queen v. Justices of Walsall, 3 C.L.R. 100 (Q.B. 1854) (under licensing statute of 9 Geo. IV, c. 61 (1828), applicant is entitled to be heard before refusal) ; Porritt, Five Centuries of Liquor Legislation in England, 10 PoL. Scr. Q. 623 (1895).

34. U.S. ex rel. Roop v. Douglass, 19 D.C. 99 (1890) ; McCormick v. Pfeiffer, 19 S.D. 269, 103 N.W. 31 (1905); Darby v. Pence, 17 Idaho 697, 107 Pac. 484 (1910); State ex rel. Billado v. Control Commissioners, 114 Vt. 350, 45 A.2d 430 (1946).

34a. See Perpente v. Moss, 293 N.Y. 325, 56 N.E.2d 726 (1944) (application for license to conduct employment agency denied; statute did not require hearing; 
history of alcoholic beverage control that due process of law requires a hearing before administrative refusal of a retail license application, the holdings that such a hearing is not a constitutional requisite, and the availability of mandamus or other remedy to correct flagrantly erroneous administrative denials ${ }^{35}$-all support the conclusion that due process of law probably does not require a hearing before administrative refusal of an application for a retail alcoholic beverage license.

This does not mean that courts should routinely accept an administrative decision to refuse hearings in the issuance process. It means only that the instrument of due process may not be available as a coercive device. Enlightened statutory construction and an insistence that administrative denial of a hearing be based on demonstrated consideration of all relevant factors can and should be used to remedy erroneous administrative denials of hearings.

\section{Hearing on Ali Applications}

At the other extreme from the practices of the relatively small group of agencies which refuse hearings in the issuance process is the requirement of two alcoholic beverage control acts that the state licensing agency grant hearings on all applications. ${ }^{36}$ The purpose of this requirement being somewhat obscure, one of the items in the questionnaire called for comment on the suggestion that the primary purpose of the requirement is to give members of the local public an opportunity to present information or objections concerning the applicant. Most administrators who expressed an opinion agreed with the suggestion. Others, including the Director of Alcoholic Beverage Control of the State of Kansas, disagreed:

"It is my opinion that the reason that a hearing is required in connection with applications is for the protection of the public interest rather than satisfaction of those who may be interested locally in the granting or denying of a license or for the benefit of the applicant. Since the Kansas act is principally a control measure rather than a revenue act and is enacted under the police

held, "Though formal hearings . . . may not be required, a license may not be refused on the ground that the applicant 'is not a person of good character' unless the applicant has fair opportunity to meet a challenge to his good character. . . .").

35. Freund, Administrative Powers over Persons and Property 110 n.7 (1928) : ". . . it ought to be the denial of a judicial remedy, not the refusal of a license by traditional non-judicial methods, against which the charge of denial of due process should be directed." BENJAMIN, ADMINISTRATIVE ADJuDication IN the STATE OF NEW YoRK 102 n.24 (1942): "In view of the remedy available by a judicial proceeding in the nature of mandamus," hearings in license issuance cases will not be required as a matter of due process. See also Bourjois, Inc. v. Chapman, 301 U.S. 183 (1937).

36. Kan. Gen. Stat. Ann. $\$ 41-318$ (Corrick 1949); Mont. Rev. Codes Ann. $\S 4-407.1$ (Supp. 1951). 
powers of the state, it is incumbent upon this office to issue licenses only to those meeting the requirements, and it is our experience that in the course of the hearing, information frequently is developed which is not reflected by the formal application and allied files. It is speculative, of course, to attempt to arrive at the reasoning of the legislature in requiring a hearing on all applications but I may state that it is neither for the benefit of the locality affected nor for the benefit of the applicant but rather in the general public interest." 37

The First Biennial Report of the Kansas Director indicates that over two-thirds of the 122 applications for retail licenses which were denied in the first year of administration of the Kansas Liquor Control Act were denied (1) because of ineligibility due to residence requirements; or (2) because of convictions, pleas of guilty, or forfeiture of bonds with respect to (a) violation of state or federal intoxicating liquor laws or (b) operating a gambling house, pandering, "or other crime or misdemeanor opposed to decency and morality." 38 Disqualification arising from these limitations sometimes will present difficult questions of fact and of interpretation of the statutory terms. But a hearing is an inappropriate procedure for ascertaining relatively simple facts available in court records concerning convictions, pleas of guilty and forfeiture of bonds. Except in the unusual case of mistaken identity or inaccuracies in the court records, information of this character gathered from the application or by the agency's investigators will not be disproved in a subsequent hearing. Usually, parties do not litigate the obvious. Advance notification of denial for such reasons would, therefore, in most instances end the matter without the delay and expense involved in a subsequent hearing.

Kansas, however, does not give applicants advance notice of "substantive objections" to issuance raised by the agency's staff. ${ }^{30}$ Instead, such objections are developed in the course of the hearing. After the hearing, the applicant is notified by formal order of the Director stating the reasons for refusal to grant the license. The applicant then may appeal to the Alcoholic Beverage Control Board of Review where he shall be given a "fair hearing." 40 On its face, such a procedure

37. Kansas Director of Alcoholic Beverage Control reply to questionnaire.

38. First Biennial Report of the Office of the Director of Alcoholic Beverage Control 16 (1950).

39. The reply of the Kansas Director of Alcoholic Beverage Control to item VI of the questionnaire (see Appendix infra) is as follows: "Formal deficiencies are brought to the attention of the applicant by letter or personal consultation prior to the hearing, and an opportunity is afforded him to correct such deficiencies. Substantive objections raised by our staff or third parties are not brought to the attention of the applicant until developed in the course of the hearing."

40. Kan. Gen. Stat. Ann. §41-321 (Corrick 1949). 
should satisfy the most zealous advocate of fairness in the administrative process, for under it the applicant may, if he elects, be given two hearings. But why should not the applicant be informed of the "substantive objections" in advance? If in fact he has been convicted of violating the liquor laws and thus is disqualified by the statute, he probably will not go through the futile process of endeavoring to convince the agency that black is white. And thereby both the applicant and the agency would be spared the time and expense involved in a hearing.

A partial answer to this argument is found in the circumstance that probably little time and effort will be needed at the hearing stage to develop the fact of prior conviction or other similarly uncontrovertible disqualifying data. ${ }^{41}$ But from the standpoint of the applicant, it is difficult to see why he should be put to any burden or expense if the agency has reliable advance information of disqualifying characteristics.

The objection to a statutory requirement of a hearing on all applications thus is that hearings are not necessary in all cases. Hearing procedures are expensive both to the state and to the applicant. Public and private resources should be conserved for more useful purposes than needless hearings.

\section{Hearing in Event of Initial Refusal}

Between the extremes of no hearings and hearings on all applications is the widely adopted procedure of granting a hearing if, after the application has been refused, the applicant seeks an opportunity to be heard. The three main variants of this procedure are: (1) hearing by the agency refusing the application; (2) hearing by a state licensing agency to which local licensing agency orders may be appealed; and (3) hearing by a court pursuant to a "de novo" review provision.

\section{A. Hearing by the Agency Refusing the Application}

The statutes of seven states provide that the licensing agency shall give the applicant a hearing in the event that the application is initially refused. ${ }^{42}$ In addition, the questionnaire replies show that a

41. See First Biennial Report of the Office of the Director of Alcoholic Beverage CoNTrol 6 (1950): "The first hearings for retail liquor licenses were set for June 27 and 28,1949 , with the director and the attorney in charge. A court reporter was contracted to record, the hearings as a matter of official record. Fifteen minutes were allowed for each hearing, and the hearings ran continuously throughout the day. On these first two days, forty-three hearings were held."

42. Cal. Gen. Laws, act 3796, §39 (Supp. 1947) ; Conn. Rev. Gen. Stat. $\$ 4261$ (1949) ; Fla. Stat. \$ 561-19 (1949); PA. Stat. ANn. tit. 47, § 4-464 (Purdon Supp. 1951); S.C. Acts 1945, No. 211, § 16; TENN. Code ANN. §6648.17(7b) (Michie Supp. 1952) (no hearing required if "application shows on its face that the applicant is not entitled to a license. . . ."); VA. CODE $\$ 4-31$ (b) (1950). 
half dozen agencies whose statutes contain no express provisions concerning opportunity to be heard do give hearings in the event of initial refusal as a matter of policy. ${ }^{43}$

In this group of states, the licensing agency receives the application, considers the data contained therein, as well as information produced by the staff's investigation, and decides whether or not to grant the application. If the decision is in the affirmative, the license is issued, and no further action is necessary. On the other hand, the agency's preliminary study may reveal defects in the application which can be readily remedied. In that event the usual course would be to inform the applicant so that he might make the necessary corrections. If the applicant fails to make the changes suggested or if, after exhaustion of the informal administrative process, the staff is unwilling to recommend issuance, the applicant is notified that the application is refused. The reasons for the refusal generally are stated. ${ }^{44}$

The procedure of considering the application in light of information found therein or ascertained from other sources, granting the application if that information is convincing, and giving a hearing in doubtful cases has the advantages of conserving administrative time and energy in clear cases and of limiting applicants' opportunity to be heard to situations where the hearing might be helpful to the applicant and the agency.

A possible objection to this procedure is that once the agency has refused the application and notified applicant of that decision, it will be unwilling in a later proceeding to change its mind; the applicant may be harmed by the preliminary decision to deny because at the hearing he will appear before an agency which already has ruled against him rather than before an unbiased tribunal prepared to decide impartially on the basis of the evidence at the hearing.

The answer to this argument is that it is extremely unlikely that in any real sense the members of the agency will have decided to deny the application. That responsibility often is delegated to the staff of the agency, with the agency members exercising only a supervisory control over staff action. It may not be accurate, therefore, to say that the "agency" has pre-judged the issue. More important, even though

43. Georgia, Michigan, Minnesota, New Hampshire, Oregon, Vermont. The Michigan reply also noted, "Hearing not granted if application cannot be considered due to provision of the Statute."

44. Returns from the questionnaire did not indicate whether in the refusal notice the applicant is notified he will be given a hearing if he requests it or whether the burden was placed on the applicant to seek the hearing without prior notice that a hearing would be granted upon request. This problem of notice could be handled by promulgating a rule to the effect that in event of initial refusal a hearing will be granted upon request; or that fact could be stated in the notice of denial. 
the notice to the applicant may be in terms of "denial," this language properly interpreted does not imply a considered decision to refuse the application, but rather an opinion on the basis of the available information that the applicant has not sustained the burden of convincing the staff or agency members of the desirability of immediate issuance. Denial in this sense is simply a preliminary, tentative statement, somewhat in the nature of an order to show cause, rather than a considered determination to refuse the application. Finally, even if it be assumed that the agency members will be unable to rid their minds of whatever bias results from their prior consideration, there appears to be no practicable alternative to the procedure under discussion. The agency of course might refuse to give any hearing in the issuance process, or at the other extreme might grant hearings on all applications. From the standpoint of the applicant, the undesirability of the first suggestion is obvious. The other suggestion is equally objectionable. Granting a hearing on all applications would, in many instances, waste the time and energy of the agency and its staff. There is no need for a hearing to determine whether to issue a license when the information at hand shows that the application should be granted.

The only valid objection to the procedure of giving a hearing in all cases of refusal is that in some instances a hearing will be unnecessary. Some licensing statutes provide that a license shall not be issued to a person who has been convicted of a felony or who has had a license revoked during a specified minimum period immediately preceding the application. ${ }^{45}$ If public or agency records disclose that applicant is such a person, it is difficult to see why a hearing should be given to determine whether the application should be refused; or if the application shows on its face that the applicant does not possess the qualifications necessary for issuance of a license, why have a hearing to determine whether he should be licensed? ${ }^{46}$

The reason most often mentioned by the licensing agencies in explaining the decision to grant hearings in event of initial refusal is that it is only "fair" that the applicant be heard before he is finally refused the privilege of engaging in the business of his choice. ${ }^{47}$ This

45. See Jornt Committee of the States to Study Alcoholic Beverage Laws, Alcoholic Beverage Control 102 (1950) (items 2 and 4 of Table 11, "Occurrence in the Laws of the Several States of Certain Criteria for Use in Selecting Persons to be Licensed").

46. Tenn. Cone Ann. $\$ 6648.17(7 \mathrm{~b})$ (Michie Supp. 1952) in event of initial refusal a hearing shall be held, "provided, that . . . it shall not be necessary to hold such hearing if the application shows on its face that the applicant is not entitled to a license. ..."

47. There was also some mention that hearings are needed in deciding some particularly difficult factual questions. 
factor of "fairness" is emphasized in Mr. Robert M. Benjamin's outstanding study of state administrative procedure as follows:

"Fairness will generally require that, to the greatest practicable extent, there should be accorded to a party an opportunity to know the reasons for proposed administrative action and the assumed facts that support those reasons, an opportunity to test and to controvert those reasons and those facts, and an opportunity to present and explain his own position before action is taken. Procedure that denies or substantially limits such opportunities must be justified by cogent considerations." 48

One situation suggested by Mr. Benjamin in which it may be appropriate to dispense with hearings in the license issuance process will exist where the personnel of the license agency is insufficient to accord hearings in all license cases. In such a case, "there is a good deal to be said for according hearings in cases of revocation, suspension or refusal to renew, and adopting some less formal procedure on the issuance of licenses." 49

A more significant reason for concluding that a hearing should not be accorded will exist wherever the nature of the question is such that the procedure of a hearing would be a clumsy or wasteful method of enlightening the agency either as to factual issues or as to the manner in which discretion should be exercised. ${ }^{50}$ With few exceptions, neither legislatures nor administrative agencies have followed the selective process of granting or denying hearings on the basis of the nature of the question at issue. The explanation for the failure to utilize the selective process may be legislative and administrative reluctance to undertake the task of defining the instances in which a hearing should be omitted because it would serve no useful purpose. The more likely explanation, at least as reflected in the questionnaire replies, is the apparent conviction of most agencies that persons who have an obvious and vital interest in administrative action should be afforded the opportunity to be heard in connection with the action. $86(1942)$.

48. Benjaxin, Administrative Adjudication in the State of New York

49. Id. at 101. There is no suggestion in the questionnaire replies that this factor of insufficiency of personnel plays an important role in the administration of alcoholic beverage control statutes.

50. Patterson, The Insurance Commissioner in the United States 393 (1927) argues that "One must not hastily assume, however, that the mere circumstance that there are no disputed issues of fact involved in the refusal of a license necessarily leads to the conclusion that a hearing need not be given before the refusal is final. Questions of judgment and discretion are as much debatable, indeed, far more debatable, than questions of "fact'." I am inclined to believe, however, that in most cases of discretion and judgment, what is needed is not so much a hearing as an opportunity to discuss or argue the policy problem with or before the decider. 
Moreover, agencies granting a hearing in event of initial refusal notify the applicant of the reasons for the refusal. If, in giving notice of initial refusal, the agency states a reason which cannot be controverted effectively in a hearing or otherwise, the rejected applicant probably will appreciate the futility of seeking a hearing. In light of this consideration, it seems fair to conclude that in this group of states, although in theory many agencies give hearings in instances in which hearings are not needed, in actual operation there probably are but few unnecessary hearings.

One factor distinguishing a procedure required by statute and a similar procedure adopted by the licensing agency in the exercise of its discretion is that the former is relatively inflexible, while the latter can quite easily be changed. Since in some instances it can be said fairly that a hearing performs no useful function, states now requiring hearings in event of initial refusal should consider the advisability of authorizing the agency to define by rule those classes of cases in which, despite an initial refusal, a hearing would not be granted because it would serve no useful purpose. Such a delegation of authority, properly drafted, would present no serious constitutional issues and would make it possible to avoid hearings where they are unnecessary. Defining the classes by administrative rule rather than by statute would facilitate revision as experience demonstrated the desirability of additions to or deletions from the enumerated classes of cases.

A few states have formalized the procedure of granting a hearing in event of initial denial by designating the officials before whom the hearing is to be conducted. ${ }^{51}$ In these states, license applications are made to a director of alcoholic beverage control. If the director refuses to issue the license, the applicant may appeal to the alcoholic beverage control board which grants a hearing on the appeal. These statutes differ from the usual hearing-after-initial-refusal provisions in that in the latter the responsibilities of initial consideration and final hearing are imposed generally on the "agency," which means that the agency may designate sections of its staff-e.g., "License Bureau," "Law Bureau"- to make the initial determination and to conduct the hearings required by the statute. In the small group of states which have formalized the procedure the statute designates both the official who is to make the initial determination and the officials who are to make the final decision after hearing. In most of these states, too,

51. Ark. Acts 1951, No. 159, §15; Kan. Gen. Stat. Ann. \$41-321 (Corrick 1949); Ky. Rev. Stat. $\$ 243.470,243.550$ (1948); Ohio Code ANn. $\$ 6064-27$ (1945). See also R.I. Laws 1940 , c. $821, \S 129$ (1) providing for appeal to the board in event of refusal of an application for a dining car company, parlor car company, etc. 
the statutes indicate that the appellate hearing is to be before the board itself rather than before a subordinate hearing officer. ${ }^{\mathbf{5 2}}$

Statutory separation of the functions of initial consideration from that of final decision, coupled with the right to a hearing before board members, certainly has the appearance of providing greater protection to applicants' interests than the more widely adopted procedure of a hearing by the "agency" which has initially disapproved the application. Whether in fact there are significant differences in the two procedures will depend not so much upon statutory framework-as important as it is-as upon the modus vivendi between the director or staff and the members of the board. Under either procedure the relationship between the director or staff and the board members can run the gamut from, at the one extreme, the board's entirely abdicating its responsibilities to, at the other extreme, the board's usurping the functions of the director or staff. Choice between the two procedures must depend primarily upon considerations having to do with combining functions and vesting responsibility in a single agency as opposed to separating functions and thereby dividing responsibility. ${ }^{53}$

\section{B. State Agency Hearing on Appeal from Local Agency Refusal Orders}

Prior to national prohibition, administration of alcoholic beverage control legislation generally was vested in local officials, with results that were not always wholesome. ${ }^{54}$ At repeal, persuasive voices urged the desirability of a "single state licensing board with state-wide authority and responsibility." ${ }^{55}$ A few states followed that recommendation and gave a state agency exclusive control; at the other extreme, some states resurrected the system of local control; but the majority of states licensing the sale of alcoholic beverages provided for local and state participation in the license issuance process. ${ }^{56}$ In the latter group, there are wide variations in the degree of responsibility allocated to local and state officials. In some, the function of the local agency is to make purely advisory recommendations to the state agency; in others, licenses must be secured from both local and state authorities or the approval of the local agency is made a condi-

52. In Kentucky the statute specifically authorizes appeals to be heard by the board "or persons designated by the board." KY. REv. STAT. $\$ 243.470$ (1948).

53. A topic which cannot fruitfully be explored in this paper. See generally, Davis, Administratrve Law c. 10 (1951).

54. Cooprider, Legal Questions in the Operation of the Licensing Systems, 7 LAW \& Contemp. Prob. 621 (1940).

55. Fosdick and Scott, Toward Liquor Control 41 (1933).

56. The Joint Committee of the States to Study Alcoholic Beverage Laws, Alcomolic Beverage Control 24-28 (1950). 
tion precedent to issuance of a state license; in still others, the licensing power is vested in the local agency, subject to the power of the state authority to reverse on appeal. ${ }^{57}$

The feature of the local-state cooperative method of license issuance of interest here is the provision in several alcoholic beverage control acts that if the local agency refuses to issue a local license or refuses to recommend issuance of a state license by the state agency, the applicant may appeal from that adverse local determination to the state agency which shall grant a "hearing" thereon. ${ }^{58}$

The system of state hearings on appeal from adverse local determinations is a direct consequence of legislative acceptance of the proposition that alcoholic beverage control should be a joint local-state responsibility. There are weighty reasons for concluding that the alcoholic beverage business should be regulated exclusively by the state. ${ }^{59}$ Under such a system there would, of course, be no occasion for appeals from local to state agencies. Once it is determined, however, that alcoholic beverage control should be a local-state venture, the procedure of appeal to the state control authority from adverse local determinations appears to be a sensible expedient for recognizing homerule sentiment while at the same time assuring centralized control.

From the standpoint of issuance procedures there are two important questions concerning state review of adverse determinations by local licensing agencies: (1) Upon what record should the state determination be made-upon the record of the proceedings before the local agency or upon the record compiled in a de novo hearing before the state agency? (2) What should be the scope of the review of the state agency-should the local determination be accepted unless it is "arbitrary," "without justifiable cause," "unreasonable," "unsupported by substantial evidence," etc., or should the state agency exercise a completely independent judgment, or should there be some intermediate solution?

The answer most often given to the first question is that the appellate determination should be based upon the record of hearing

57. Ibid. See also Harrison AND LAINE, AFtER REPEAL 48-52 (2d ed. 1936); Chinds, Making Repeat Work 105-106 (1947).

58. ILL. ANN. STAT. c. 43, $\$ 153(1944)$ appeals from local licensing agencies in cities having a population of over 200,000 go to a special License Appeal Commission consisting of the Secretary of State, the Chairman of the Illinois Liquor Control Commission and a third member selected by the local governing board; this provision has been described as "nothing but a concession to Chicago politicians." HarRISON AND LAINe, AFter Repeal 91 (2d ed. 1936); KY. Rev. Stat. \$\$241.150, $241.200,243.500$ (1948) ; Me. Laws 1951, c. 57, \$12; MAss. ANN. LAws c. 138, $\$ 12$, 67 (1949); Neb. Rev. Stat. \& 53-1.115 (1943); N.J. Rev. Star. ANN. \$33:1-22 (Supp. 1951) ; N.Y. Alcoholic Beverage Control LAW \$54.3 (1946); R.I. Laws 1948, c. 2124, \$2; TenN. Code ANn. \$6648.17(7b) (Michie Supp. 1952).

59. Fosdick and Scotr, Toward LrQUoR Control 41 (1933). 
before the state agency. ${ }^{60}$ This is clearly a desirable conclusion in those states in which the local determination is not based on a hearing and record which can be certified to the appellate agency, for whatever the scope of review, it is difficult to see how a state agency can review intelligently the local determination in the absence of a full development of the relevant facts. ${ }^{61}$ On the other hand, if the local agency grants a hearing and a record is compiled, no very significant reason exists for going through the same process on the state level.

In the rare instance in which the state agency decision to conduct a de novo hearing has been challenged, the appellate court has sustained the de novo procedure. In Baginski v. Alcoholic Beverage Commission, ${ }^{62}$ the Supreme Court of Rhode Island held that the statute-which vested in the state commission "the right to review the decision of any local board, and after hearing, to confirm or reverse the same in whole or in part, and to make such decision or order as it shall deem proper" ${ }^{63}$-gave the state commission sound discretion to hear appeals de novo either in whole or in part.

The court's opinion points out that prior to national prohibition alcoholic beverage control in Rhode Island was vested almost exclusively in local governing bodies and that under that system local decisions were judicially reviewed by writs of "common law certiorari," under which the reviewing court confined its examination of the record made below to determine whether or not the local body "had committed error of law." The result was "lack of uniformity" and "grave abuses which, as a matter of common knowledge, affected the public welfare." In light of these considerations, the court concluded that, in providing for review by the state commission, the purpose of the legislature was to prevent the return of the evils peculiar to the old system of local regulation, and that the legislature therefore "intended"

60. Illinois: "tried de novo," statutory requirement; Kentucky: "All decisions shall be based upon the evidence developed at the hearing," Ken. Alc. Bev. Cont. Board Reg. LC 16, June 13, 1944; Nebraska : "tried de novo," statutory requirement; New Jersey: "heard de novo" with stated exceptions, N.J. Div. of Alc. Bev. Cont. Regs. No. 15, Rules 6 and 8 (1950) ; New York: "de novo hearing," questionnaire; Rhode Island: "de novo," Baginski v. Alcoholic Beverage Commission, 62 R.I. 176, 4 A.2d 265 (1939); Tennessee: TENN. CODE ANN. \$6648.17(7b) (Michie Supp. 1952). The Massachusetts statute is unclear, and the questionnaire reply was not responsive on this point. Maine gives a de novo hearing but by statute the evidence at the hearing "shall be limited to the reasons specified" by the local licensing agency as the reasons for refusal of the license. Statutory references in this note are the same as appear supra note 58.

61. Unless, of course, the local denial is based upon a fact as to which a hearing would shed no light. See also N.J. Div. of Alc. Bev. Cont. Regs. No. 15, Rule 8 (1950): "Where none of the material facts is disputed, the appeal may be presented, subject to the approval of the Director, upon an agreed statement of facts."

62. 62 R.I. 176, 4 A.2d 265 (1939); accord, Kaskela v. Daneker, 76 R.I. 405, 71 A.2d 510 (1950).

63. R.I. Laws 1938 , c. 164 , § 9 . 
to vest in the state commission "the broadest, rather than the narrowest, power over local bodies in order to insure a state-wide conformity to the law."

The court also emphasized that in this and other cases in Rhode Island, "the record which comes up to the commission from the local board . . . is of the scantiest kind, containing little, if anything, more than a bare statement of the [local] board's decision." Administrators in other states have noted the "informal" character of the local "hearings." 64 These observations, coupled with the report of the Rhode Island practice, are strong evidence that in those few states in which the local agency provides a "hearing," 65 the "hearing" given by the local agency is not the kind which would provide a record on the basis of which the state agency could exercise its appellate function. It is a fair conclusion therefore that in nearly all instances, a de novo state agency hearing will be necessary and desirable.

The problem of the scope of review is more complex and troublesome. The statutory and administrative formulae purporting to govern the scope of state review of local agency determinations are at the one extreme that the state agency exercises a "completely independent" judgment, ${ }^{68}$ and at the other, that the state agency is limited to determining whether the local decision is "unreasonable," 67 "arbitrary," "8 "without justifiable cause," ${ }^{99}$ an "abuse of discretion," 70 or "unsupported by substantial evidence." 71

Judged solely on the basis of the words used, the "completely independent" standard provides for significantly greater state control than the other standards mentioned. Yet it has been said of the related problem of the scope of federal judicial review of administrative determinations: "Whether the variations [in the standards] usually make any real difference in the judges' actual treatment of administrative orders, and how much difference, can only be guessed." 72 If this is true of law-trained, life-appointed federal judges "guided by

64. Illinois: "extremely informal"; Maine; "rather informal."

65. The three states whose questionnaire replies indicated that "hearings" are given by the local agency are Maine, Nebraska, and Rhode Island.

66. New York (questionnaire reply); Rhode Island (questionnaire reply).

67. Illinois (questionnaire reply).

68. Maine (Me. Laws 1951, c. $356, \S 12$ ); Illinois (questionnaire reply).

69. Maine (Me. Laws 1951 , c. $356, \S 12$ ).

70. New Jersey (Hudson Bergen County Retail Liquor Stores Ass'n v. Board of Com'rs, 135 N.J.L. 502, 52 A.2d 668 (1947); see also N.J. Div. of Alc. Bev. Cont. Regs. No. 15, Rule 6: ". . . the burden of establishing that the action of the [local licensing agency] was erroneous and should be reversed shall rest with the appellant.").

71. Illinois (questionnaire reply).

72. Rep. Atr'y Gen. Comm. Ad. Proc. 90 (1941). 
a code of ethics evolved from the tradition of the profession centuries old" 73 in reviewing determinations by important federal administrative agencies, what shall be said in the case of relatively low-paid state officials, not subject to the same restraining influences, who review determinations of minor local officials? The conclusion is irresistible that, in any particular instance of state review of a local decision, factors other than the verbal formulation of the standard play a significant, perhaps decisive, role in determining the scope of review. Among these factors are the following:

The strength of the home-rule sentiment in the state in question. This factor is fully developed by the Supreme Court of Rhode Island in Baginski v. Alcoholic Beverage Commission, ${ }^{74}$ discussed above. ${ }^{75}$

The constituency of the local licensing agency. If the local licensing agency is the local governing body-town council, board of supervisors, etc.- - there is somewhat less reason for the state agency to defer to the adverse local determination than if the members of the local agency are appointed officials whose sole or primary task is to administer the local licensing law. Members of local governing bodies are elected because of local political influences or for other reasons having little to do with the capacity to exercise an intelligent, dispassionate judgment concerning individual cases of license application. This is not to suggest that members of local governing bodies are corrupt individuals incapable of exercising an objective judgment on license applications, or, conversely, that persons appointed to local licensing agencies are paragons of administrative competence unaffected by political considerations. The rather narrow point is that in the main, decisions of persons specifically selected to discharge decisional responsibility are entitled to greater respect than decisions of persons elected primarily to discharge other responsibilities.

The procedure utilized by local agencies in reaching their decision. This should perhaps be the most important of all the factors. A hearing and a decision based on the record compiled at the hearing are no assurance either that all relevant facts and arguments will be developed or that the decision reached will be just or untainted by extraneous considerations. But such a procedure is conducive to reasoned determinations. The utilization of such a procedure by local agencies should be a factor limiting the scope of state review. ${ }^{76}$

73. Vanderbilt, The Place of the Administrative Tribunal in Our Legal System, 24 A.B.A.J. 267, 272 (1938).

74. 62 R.I. 176, 4 A.2d 265 (1939).

75. See text at note 62 supra.

76. See N.H. Fire Ins. Co. v. Murray, 105 F.2d 212, 217 (7th Cir. 1939); Cooper, Administrative Agencies and the Courts 346 (1951). 


\section{Court Hearing on Appeal}

The third variant of hearing after initial refusal is found in five states whose alcoholic beverage control acts provide for "de novo" court review of an administrative refusal to issue a license. ${ }^{77}$ Taken literally, these statutes would seem to require the court to conduct a new hearing and, exercising its independent judgment on the evidence adduced at the hearing, to decide whether or not the license should be issued. This appears to be the view of the Supreme Court of Arizona. ${ }^{78}$ Such an approach makes the court the real licensing agency and correspondingly diminishes the authority and importance of the administrative agency.

Quite apart from the consideration that some state constitutions prohibit imposing administrative duties such as license issuance on the judiciary, ${ }^{79}$ there are weighty practical reasons for not making courts super-licensing agencies. Most important, it is a poor use of community resources to establish an administrative agency to supervise the alcoholic beverage business and then permit or direct another branch of government to duplicate its work. This objection of wasteful duplication of effort is particularly applicable to those states in which license applicants are given administrative hearings on their applications. ${ }^{80}$ A second reason why courts should not become superlicensing agencies is that licensing by the various lower court judges makes difficult if not impossible the uniform application of the law that can be achieved when a single state-wide agency administers the alcoholic beverage control act. Other objections which have been advanced against licensing by the judiciary are that administrative

77. Ariz. Code Ann. \$72-109(c) (Supp. 1951) ; LA. Rev. Stat. tit. 26, § 302 (1950); N.M. Stat. ANN. \$61-516 (Supp. 1951); PA. Stat. ANN. tit. 47, \$ 464 (Purdon Supp. 1951) ; Tex. Pen. Code ANN. art. 666-14 (1938), art. 667-6(e) (Supp. 1951). See also Kan. Gen. Stat. Ann. \$41-323 (Corrick 1949) (appeal shall be heard "as an equity proceeding and shall proceed as an original action."). See generally, Note, De Novo Judicial Review of State Administrative Findings, 62 HARV. L. REv. 1217 (1952).

78. Duncan v. Mack, 59 Ariz. 36, 42, 122 P.2d 215 (1942) (appeal is to be heard in the same manner as though it were an original proceeding; although "as a matter of practice due consideration should be given to the opinion of the lower tribunal as to the weight and credibility of the evidence, yet the superior court has jurisdiction to disregard that opinion and form its own independent conclusions upon the evidence.").

79. See De Mond v. Liquor Control Commission, 129 Conn. 642, 30 A.2d 547 (1943); Yarbrough v. Montoya, 54 N.M. 91, 214 P.2d 769 (1950).

80. In this group of states administrative hearings are given in event of initial refusal in Pennsylvania (PA. STAT. ANN., tit. $47 \$ 464$ (Purdon Supp. 1951)), in Texas on all applications for beer licenses (TEX. PEN. CODE ANN. art. 667-6 (Supp. 1951)), and in Louisiana if issuance of the license is opposed (LA. REv. STAT. tit. $26, \S 85(1950))$. 
officials are better equipped to make the licensing determination and that giving courts such a prominent role in the licensing process puts the judiciary too deeply into politics. ${ }^{81}$

Considerations such as these probably explain why the Supreme Courts of New Mexico and Texas have not given the de novo appeal provisions of their alcoholic beverage control statutes a literal interpretation. These courts hold that in a de novo appeal the function of the reviewing court is not to exercise an independent judgment but rather to determine whether the administrative decision is "reasonably supported by substantial evidence" or is "unreasonable, arbitrary or capricious." 82 The basis for the judicial determination is the evidence introduced at the judicial hearing on appeal. In the words of Chief Justice Maltbie of the Supreme Court of Errors of Connecticut interpreting a de novo appeal provision later repealed:

"Previous to the enactment of the [de novo appeal provision of the] statute, we held that in appeals under this act as in other similar situations the question for the court to determine was whether the commission acted arbitrarily, illegally or in abuse of its discretion, and that this was to be determined upon the basis of the proceedings before it, if they were available, or upon a finding of facts by the court upon the assumption that these were the facts upon which the commission acted. . . . Evidently the requirement that there be a trial de novo was intended to change this method of determining an appeal from the liquor control commission. The issue is still, was there legal and reasonable ground for its action; but the court, in reaching its decision, is not confined, as heretofore, to the facts actually or assumed to have been proven before the commission; it conducts an independent inquiry. In this sense only is the trial de novo." ${ }^{83}$

This interpretation of a de novo appeal provision limits the scope of judicial review, but the court in exercising its limited reviewing powers is not confined to the record of the administrative proceeding. To the extent therefore that the evidence introduced in the judicial hearing is the same as has been introduced in the administrative hearing, there is a wasteful duplication of effort. This objection may not be applicable to the New Mexico procedure, for in that state the administrative agency apparently does not grant a hearing in issuance

81. Childs, Making Repear Work 109, 180 (1947) ; McGeary, Pennsylvania AND THE LIQUOR BUSINEGS 7 (1948).

82. Yarbrough v. Montoya, 54 N.M. 91, 92, 214 P.2d 769, 773 (1950); Jones v. Marsh, 148 Tex. 362, 369, 224 S.W.2d 198, 202 (1949).

83. De Mond v. Liquor Control Commission, 129 Conn. 642, 645, 30 A.2d 547, 549 (1943). 
cases. ${ }^{84}$ But in Texas, where there is an administrative hearing on application for beer licenses, ${ }^{85}$ duplicative hearings would result.

Such duplication could be avoided by requiring the introduction of the record of the administrative hearing in the court proceeding and by refusing to permit the introduction of additional evidence unless in the discretion of the court there were reasonable grounds for failure to adduce such evidence at the hearing before the agency. But while it is relatively easy to interpret a de novo appeal statute to mean either a limited scope of review based on evidence adduced at the court hearing ${ }^{86}$ or an independent judgment based on the record of the proceedings before the administrative agency, ${ }^{87}$ it is more difficult to conclude that a de novo appeal involves both limited scope and decision on the administrative record. ${ }^{88}$ Combining the limited scope of review approach of the Texas and New Mexico courts with the requirement of review on the administrative record in effect converts de novo review to a certiorari review. In providing for a de novo appeal, the legislature must have meant something different from the substantial equivalent of review by writ of certiorari.

But once a court has limited the scope of review to deciding whether there is substantial evidence to support the administrative fact determination, or whether the administrative action is arbitrary, capricious, etc., the only significant advantage of a re-trial before the court is that to the extent the demeanor of witnesses and parties is important, the court's opportunity to observe them places it in a better position to determine the substantiality of the evidence. If this is the only or principal reason for a judicial re-trial, the legislative purpose can be realized and some duplication avoided by requiring the administrative record to be introduced in the judicial hearing and permitting any party to the appeal to call only those witnesses the observance of whose demeanor would, in the opinion of the court, better enable it to pass on the substantiality of the evidence.

Such a review procedure would be far from ideal. But it would reflect a workable adjustment of the interest of the legislature in requiring more than a certiorari-type review and the interest of the

84. See Yarbrough v. Montoya, 54 N.M. 91, 214 P.2d 769 (1950) (hearing not given). But in the reply to the questionnaire it is stated that a hearing is given in event of initial refusal and the applicant thereafter requests a hearing.

85. Tex. Pen. Code ANn. art. 667-6 (Supp. 1951).

86. See cases cited in note 82 sipra.

87. Denver \& R.G.W. Ry. v. Public Service Commission, 98 Utah 431, 100 P.2d 552 (1940).

88. But cf. Texas Liquor Control Board v. Floyd, 117 S.W.2d 530 (Tex. Civ. App. 1938). 
judiciary in not becoming either a super-licensing agency or a participant in wasteful duplication of governmental action.

Of all the states utilizing the de novo appeal procedure, the experience of Pennsylvania is the most illuminating and is an object lesson of the shortcomings of a system of de novo appeals. Pennsylvania's sad record is traceable in large part to the defects inherent in any de novo appeal procedure. It is attributable also to the statutory provision that there "shall be no further appeal" from the de novo determination of the county court of appeal to the appellate courts of the state. ${ }^{89}$

The provision of the Pennsylvania Liquor Control Act for de novo appeal combined with the prohibition of appeals to the appellate courts drastically diminished the authority of the Pennsylvania Liquor Control Board, and in effect made the local courts of the sixty-seven counties of the state independent local licensing agencies. The only limitation on the power of the county courts of appeal was the Pennsylvania doctrine that where a statute expressly prohibits an appeal from a lower court to an appellate court, the latter may nevertheless review the lower court's action by an appeal "in the nature of a certiorari." 90 The scope of review in this "restricted or narrow" certiorari is limited to "the question of jurisdiction and the regularity of the proceedings; the merits of the controversy cannot be considered even though the interpretation given to the facts or law by . . . the court below may have been erroneous." 91

The prophecy expressed in an early case, that the effect of the de novo review provision coupled with the prohibition of appeals would "be to do away with uniformity of decision . . . for no court of quarter sessions is bound by the decision of another court of equal authority," proved only too accurate. ${ }^{92}$ With few exceptions, the

89. PA. Stat. ANN. tit. 47, \$744-404 (Purdon Supp. 1950). The county court of appeal is the court of quarter sessions of the county in which the premises proposed to be licensed are located or the county court of Allegheny County. The appellate courts are the Superior Court and the Supreme Court.

90. Note, Pennsylvania Certiorari and Review of Questions of Law, $98 \mathrm{U}$. oF PA. L. REv. 733, 738-740 (1950).

91. Kaufman Construction Co. v. Holcomb, 357 Pa. 514, 55 A.2d 534 (1947). See also Commonwealth v. Hilderbrand, 139 Pa. Super. 304, 11 A.2d 688 (1940), distinguishing between the Superior Court's scope of review in license issuance cases, where the statute prohibits further appeal, and the scope of review in license revocation cases, where the statute neither prohibits nor authorizes further appeal. In the former the scope is as stated in the text. In the latter the appeal to the Superior Court "is treated as a certiorari ... in its broadest sense"; the question on appeal in such cases is "whether the court committed an error of law or abused its discretion" Commonwealth v. Hilderbrand, supra at 308, 11 A.2d at 690 ; accord, Blair Liquor License Case, $158 \mathrm{~Pa}$. Super. 365, 45 A.2d 421 (1946).

92. McGettigan's Liquor License Case, 131 Pa. Super. 280, 286, 200 At1. 213, 215 (1938). And see Elmen's License, 51 Pa. D. \& C. 477, 483 (1944): "On the question of the powers of the board, there are no appellate court decisions and the lower 
Pennsylvania appellate courts permitted the county courts to proceed about as they saw fit. ${ }^{93}$ The result was that some county courts, with the consent of the parties, decided the appeal on the basis of the record before the Liquor Control Board; others insisted that there be a complete re-trial before the court. ${ }^{94}$ In some counties the scope of review was limited to determining whether the Board "has abused its discretion" or whether the Board's action was "arbitrary or unreasonable"; ${ }^{95}$ in other counties the courts held that they should hear and decide the appeal "without reference to any action that the board may have taken and determine whether" in the court's judgment the license should be granted. ${ }^{96}$ For a long period the Liquor Control Board and the courts of several counties differed over the interpretation of the Quota Limitation Act, ${ }^{97}$ with the result that in some counties quota limitations did not apply to club licenses, or to liquor licenses exchanged for beer licenses, whereas in other counties those licenses were subject to quota limitations. ${ }^{98}$ Approximately one-third of the applicants whose applications were refused by the Board appealed to the courts; over two-thirds of these appeals were successful. ${ }^{99}$

A procedure which results in such an uneven interpretation and application of the law, which makes the central control authority subordinate to the local judiciary, and which requires wasteful, duplicative hearings certainly has little to commend it. The 1949 action of the Pennsylvania General Assembly in repealing the no-further-appeal prohibition and expressly authorizing appeals from the county courts to the Superior Court ${ }^{100}$ has enabled that court to correct one of the

court decisions throughout the state are in direct and hopeless conflict. Therefore, whatever conclusions we may reach in the instant case will but add one more decision to one side or the other of the prevailing conflict."

93. The most significant appellate restraint on the almost unlimited power of the county courts of appeal was the rule developed by the Superior Court that as to matters concerning which the Liquor Control Board has "discretion," the county court could not reverse or modify the administrative order unless the court made findings of fact different from those made by the Board. This doctrine was most often applied in revocation or suspension proceedings. See Azarewicz Liquor License Case, $163 \mathrm{~Pa}$. Super. 459, 62 A.2d 78 (1948).

94. Childs, Making Repeal Work 179 (1947); McGeary, Pennsylyania AND THE LIQUOR Business 59 (1948).

95. Cedar-Rest, Inc. License, 11 Monroe Leg. Rep. 86 (1948); Appeal of West Scranton Democratic Club, 57 Pa. D. \& C. 447 (1946); In re Appeal of Matz, 35 Luz. Leg. Rep. 281 (1940).

96. In re Ten to Six Club, 52 Pa. D. \& C. 609 (1945); In re Liquor License of Reading Company Boosters Club, Inc., 36 Berks L.J. 75 (1943) ; Privol's Appeal, $20 \mathrm{~Pa}$. D. \& C. 163 (1934); but cf. In re Appeal of Junior Fire Company Home Association, 38 BrRKs L.J. 61 (1945).

97. Pa. Stat. Ann. tit. 47, \$744-1002 (Purdon 1941).

98. McGeary, Pennsylvania and the Liguor Business 57-58 (1948).

99. $I d$. at $58-59$.

100. Act of May 20, 1949, P.L. 1551; now PA. Star. ANn. tit. 47, §4-464 (Purdon Supp. 1951). 
glaring inequities of the previous system: in Goodzeill Fire Co. License Case ${ }^{101}$ the Court held that the Quota Limitation Act is applicable to club licenses. It is quite apparent from this and other recent opinions of the Superior Court that henceforth it will not in any way defer to the county courts on important questions of statutory interpretation. ${ }^{102}$

But no matter how enlightened has been or will be the interpretation of de novo review provisions by the Pennsylvania Superior Court or the appellate courts of the other states concerned, the fact remains that a de novo review procedure causes wasteful duplication, diffuses rešponsibility, hinders uniform application of licensing standards, and tends to put the judiciary into politics. Certainly the legislatures of the states in question should seriously consider remedial measures.

\section{Third Persons' Opportunity to Be Heard}

A license applicant may be relied upon to advance facts and arguments designed to induce the licensing agency to issue the license. The responsibility of the licensing agency on the other hand is to refuse issuance unless the applicant demonstrates compliance with applicable legislative and administrative requirements. The license issuance process thus involves primarily these two groups: applicants and licensing agencies.

But persons other than these two primary parties may seek to participate in the license issuance process-usually in opposition to issuance of the license. Persons in this category may be classified into two general groups: (1) those whose opposition to issuance derives principally from what may be termed personal or broadly social considerations; (2) those whose opposition derives primarily from competitive economic considerations. Included in the first group are law enforcement or other officials of the local political subdivision in which the proposed establishment will be located, authorities in charge of public or charitable institutions located near the proposed establishment, and residents or taxpayers of the local political subdivision in which the proposed establishment will be situated. Included in the second group are persons who have applied for a single mutually exclusive license, existing licensees with whom the applicant, if granted

101. $166 \mathrm{~Pa}$. Super. 42, 70 A.2d 706 (1950).

102. Interstate Company Liquor License Case, 170 Pa. Super. 174, 84 A.2d 790 (1951); Conemaugh Club Liquor License Case, 168 Pa. Super. 589, 80 A.2d 606 (1951); Liberty Fireman's Social Club Liquor License Case, 168 Pa. Super. 500, 79 A.2d 112 (1951); Di Rocco Liquor License Case, 167 Pa. Super. 381, 74 A.2d 501 (1950); Pine Grove Hose, Hook and Ladder Co. No. 1 Liquor License Case, 167 Pa. Super. 194, 75 A.2d 15 (1950). 
a license, will compete, and trade associations of persons previously licensed.

\section{A. Hearing in Event of "Personal" or "Social" Opposition to Issuance}

A few alcoholic beverage control acts contain explicit provisions that local officials, ${ }^{103}$ or authorities in charge of public or charitable institutions located within a specified distance of the proposed establishment, ${ }^{104}$ shall be notified of the pendency of an application and be given an opportunity to be heard in the license issuance process. Legislative acceptance of the proposition that there should be some local participation in alcoholic beverage control probably accounts for the requirement that local officials be afforded an opportunity to be heard. Different considerations explain the requirement that authorities in charge of public or charitable institutions located near the proposed establishment be given an opportunity to be heard on the license application. In such a case, establishment of an alcoholic beverage business near the institution may seriously hinder the institution in accomplishing its public or charitable mission. Authorities in charge of the institution presumably are in the best position to advance facts and arguments concerning the manner in which the institution's work would be impeded if the application were granted; therefore they should be given an opportunity to be heard. Also, whenever the legislature has decided either that location near an institution is a factor to be considered by the licensing agency ${ }^{105}$ or that location within a certain distance of an institution is prohibited, ${ }^{108}$ it is understandable that the legislature also should conclude that the institution as the beneficiary of legislative action should be heard when the legislative grant is in danger of being violated. ${ }^{107}$

It is considerably more difficult to ascertain the rationale of the more common requirement that opportunity to be heard shall be af-

103. Cal. Gen. Laws act 3796, \$21 (Supp. 1947); N.M. Stat. Ann. \$61-516 (Supp. 1951). Compare WASH. REv. CODE $\$ 66.24 .040$ (1952) (local governing board may file "written objections" and make "oral argument" in support thereof).

104. Onto Gen. Cope Ann. \$6064-16 (Supp. 1951), applied in Meyer v. Dunifon, 88 Ohio App. 246, 94 N.E.2d 471 (1950).

105. E.g., Conn. Rev. Gen. Stat. §4263 (1949); Pa. Stat. Ann. tit. 47, \$4-432d (Purdon, Supp. 1951). For further detail see the chart, "LEGISLATIoN Regulating Conduct and Location of Premises," Marketing Laws Survey, State LiQUOR Legislation 127-155 (1941).

106. E.g., Fla. Stat. $\$ 561.44$ (1949); Me. Laws 1949, c. 349, \$101. For further detail see the chart referred to supra note 105.

107. See Azarewicz Liquor License Case, $163 \mathrm{~Pa}$. Super. 459, 461, 62 A.2d 78 (1948) ("Since the statute provides that the board may refuse a license for premises within 300 feet of a church, the legislative intent is clear that a church has a direct interest to protect and to be protected, and was given a status above and different from that of a remonstrant.") 
forded to a "resident," 108 "person," 100 "taxpayer," 110 "citizen," 111 et al., ${ }^{112}$ who protests issuance of the license. ${ }^{113}$ Although community sentiment may be a factor to be considered by the licensing agency, that sentiment can be ascertained through cheaper and more expeditious means than giving members of the community an opportunity to be heard. In Arizona, for example, protestants are required to submit "written objections." 114 Even if the protestant has information which would disqualify the applicant, that information can be transmitted to the agency personally or by letter, and the agency staff can develop the disqualifying evidence as part of its case in opposition to issuance of the license. Viewed in this light, there appears to be no very compelling reason for affording ordinary protestants an opportunity to be heard.

This conclusion quite clearly has not been accepted by the legislatures of the states in question; and it has been rejected as a matter of policy by many administrators. ${ }^{115}$ In an effort to ascertain the reason for the requirement that ordinary protestants be given an opportunity to be heard, the questionnaire contained an inquiry concerning the probable reason for permitting a single "citizen," "resident," "person," or "taxpayer" to be heard in the license issuance process. The answers ranged from New York's laconic "No opinion" to New Jersey's reply that a "Statutory provision for hearing even a single objector would appear to recognize the principle of correlative and co-equal rights of two citizens (applicant and objector) whose interest may be adverse in a matter of public interest as opposed to one purely private." The point made by most administrators replying to this inquiry was that affording ordinary protestants an opportunity to be

108. ILL. ANN. Stat. c. $43, \$ 153$ (1949) (resident may appeal to state commission for trial de novo); NEB. Rev. STAT. §53-1,115 (1943) (ibid).

109. LA. Rev. Stat. tit. 26, \& 85.C (1950) (liquor license applications).

110. N.J. Stat. ANN. tit. 33, c. 1, §33:1-22 (Supp. 1951) (taxpayer or “other aggrieved person" opposing issuance may appeal to state commissioner for trial de novo).

111. La. Rev. Stat. tit. 26, §283.C (1950) (beer license applications); Tex. Pen. Code AnN. art. 667-6 (Supp. 1951).

112. See Conn. Rev. Gen. Stat. $\$ 4259$ (1949) ("ten residents" may remonstrate and commission may "in its discretion" hold a hearing); Del. Laws 1941, c. $275, \S 2$ ("ten residents of the neighborhood").

113. A few states apparently give hearings only if there are protests. Del. Laws 1941, c. 275, $\$ 2$ (confirmed in questionnaire reply); LA. REv. STAT. tit. 26, $\$ 85 . C$ (1950) (no questionnaire reply).

114. Arrz. Code AnN. \$72-105 (Supp. 1951).

115. With few exceptions (e.g., New York which felt that full participation by protestants "would unduly delay determinations"), the replies to the questionnaire indicated that either because of statutory compulsion or administrative policy, protestants were entitled to full participation with the right to introduce evidence, cross-examine, etc. 
heard would better inform the licensing agency concerning the advisability of granting or denying the application. ${ }^{118}$ Since a prime purpose of a hearing is to enlighten the licensing agency, it seems legitimate to conclude that such protestant participation as contributes to that objective should be encouraged.

The enlightenment achieved in this fashion may be purchased at too high a price. If in fact the agency's staff satisfactorily performs its function, it will fully develop the case against issuance-and most likely with more speed and less cost than if protestants also introduce evidence and cross examine. But there can be no doubt that in some instances some agency staffs would be less able or less diligent in developing the case against issuance than would be private counsel retained by protestants. In such cases, the public interest would be served by permitting protestant participation. On the other hand, if the agency is well staffed with able personnel, it is unlikely that giving protestants a hearing - as distinguished from permitting them informally to furnish information or objections-will contribute materially to the desideratum of informed administrative action.

Perhaps then resolution of the policy question of whether ordinary protestants should be heard in the issuance process should depend upon the agency's judgment as to the capacity of its staff fully to perform its responsibilities. If the agency is understaffed, or salary limitations prevent recruitment of capable personnel, a liberal policy of protestant participation might be followed. Conversely, if the agency has an able staff in which it has confidence, it might limit protestants to filing oral or written statements of objection.

Solving the problem on the practical basis of whether protestant participation will better inform the agency may oversimplify the issue. Licensing unqualified retailers can create serious community problems. Establishment of an outlet for on-premise consumption in or near a residential neighborhood may bring about a reduction in property values; it may also create a hazard for the youth of the neighborhood. For these and other reasons members of the community or neigh-

116. Several administrators also stated that since their control statute required public notice of the application for license, the inference is that the legislature "intended" that members of the public to whom the notice is addressed are entitled to be heard on the application. The only appellate judicial authority is to the contrary: In the absence of a statutory provision for a hearing of the protest, a publication requirement does not require a hearing in event of protest; instead, "protests may be in writing or orally." Yarbrough v. Montoya, 54 N.M. 91, 97, 214 P.2d 769, 772 (1950). The conclusion that a publication does not of itself carry the implication that a hearing must be granted in event of protest unquestionably is sound. It is not a usual legislative or administrative practice to give a hearing to persons not the primary parties to the proceeding. If the legislative purpose is to depart from the general practice and give a hearing to those who protest, that purpose should be clearly articulated. 
borhood may have or feel they have a vital interest in seeing to it that there is full compliance with the restrictive provisions of the applicable alcoholic beverage control act. Unless there are strong reasons to the contrary, persons whose vital interests are being affected by administrative action of an adjudicative nature should be heard when those interests are in jeopardy. Not only will their participation most likely assist in developing all the relevant facts and arguments but their legitimate feelings that they should be heard will be satisfied. ${ }^{117}$

Moreover, encouraging participation of this character should tend to counteract undesirable political or pressure group influences on the licensing agency. ${ }^{118}$ In theory, administrative agencies represent and protect the public interest. In practice, only too often "our commissions have been run by officials who are merely the pale reflection of the very interests they are supposed to regulate." 119 The dangers of political control of licensing agencies are amply demonstrated by the history of alcoholic beverage control before the Eighteenth Amendment; ${ }^{120}$ and there is no reason to believe that political influence is non-existent today. ${ }^{121}$ One means of combatting political or pressure group influences is to encourage participation in the issuance process by those who have an interest adverse to the applicant. Adversary hearings of course will not prevent a venal licensing agency from operating venally. But adversary hearings, involving as they do a decision on the record, will make it somewhat more difficult for such an agency to disregard the statutory standards, particularly if the protestant also is accorded a right to judicial review. ${ }^{122}$

117. "In a government like ours, entirely popular, care should be taken in every part of the system, not only to do right, but to satisfy the community that right is done." 5 Writings and Speeches of Daniel Webster 163 (1903), quoted by Mr. Justice Frankfurter in Joint Anti-Fascist Refugee Committee v. McGrath, 341 U.S. 123, at 172, n. 19 (1951). See also BenJamin, Administrative Adjudication IN THE State OF NEW YORK 86 (1942).

118. Hale, Hearings: The Right to a Trial with Special Reference to Administrative Powers, 42 ILL. L. REv. 749, 750-751 (1948).

119. Herring, Public Administratton and the Public Interest 178 (1936). See also Fesler, The Independence of State Regulatory Agencies 71 (1942) citing "liquor regulating boards" as examples of administrative agencies "where the selfish interest of the business regulated lies in undermining the effectiveness of regulation, and where there are no well-organized supporters of the agencies' work."

120. Nat. Comm. on Law Obs. and Enf., Report on the Enforcement of the Prohibition Lazes of the United States, H.R. Doc. No. 722, 71st Cong., 3d Sess. 6 (1931); Byse, Alcoholic Beverage Control Before Repeal, 7 Law \& Contearp. Pros. 544, 551 (1940).

121. Note, The Appearance of Legislators as Private Connsel in State Administrative Adjudications, 98 U. of PA. L. Rev. 412 (1950).

122. Goodnow, Private Rights and Adninistrative Discretion, 41 A.B.A. REP. 408, 422 (1916); Note, Statutcry Standing to Review Administrative Action, 98 U. OF PA. L. REV. 70, 74-75 (1949). 
Considerations such as these may explain why so many legislatures and administrators have given protestants an opportunity to be heard in issuance cases.

In an area in which there are so many variables, generalizations are suspect. Nevertheless, three are hazarded. First, ordinary protestants probably should be given an opportunity to participate in all cases in which licenses are issued by local agencies, both because local agencies are apt to have staffs less able than state agencies' staffs and because political influences are likely to be more pervasive on the local level. ${ }^{123}$ Second, ordinary protestants should be accorded the right to appeal to state agencies authorized to review local agency determinations. ${ }^{124}$ Unless protestants can appeal to the state agency, there is little likelihood that the supervisory authority of the state agency will be exercised, for it is apparent that successful applicants will not appeal. Third, protestants, like applicants, should be heard where the data or issues involved are of a character that can best be tested or verified in an adversary, cross-examination procedure. ${ }^{125}$

\section{B. Hearing in Event of "Economic" Opposition to Issuance}

Some groups have obvious economic reasons for opposing issuance. These include persons applying for a single mutually exclusive license, existing licensees with whom the applicant, if granted a license, will compete, and trade associations of existing licenses. Does, or should, such an economic interest entitle them to an opportunity to be heard?

(1) Mutually Exclusive Applications. Some states, apparently impressed with the argument that an excess of retail outlets leads to undesirable consequences, have limited the number of retail licenses that can be issued. Limitation legislation of this type generally provides that no new license shall be issued in a particular subdivision where the ratio of existing licenses to population exceeds the statutory proportion. ${ }^{128}$ Other states have instructed their licensing agencies to take into consideration such factors as public convenience and advantage, public interest, or the reasonable demand of the public. ${ }^{127}$

123. Goodnow, op. cit. supra note 122 . See also Dickinson, Administrative JUSTICE AND THE SUPREMACY OF THE LAW 256 (1927).

124. Moretti v. Division of Intoxicating Beverages, 62 R.I. 281, 5 A.2d 288 (1939), narrowly limiting the right to appeal to the state agency is opposed to the thesis expressed in the text. For the reasons given in the dissenting opinion, the holding seems clearly incorrect.

125. Thus if the protestant is merely recording his views as a member of the community, there is no reason for granting him an opportunity to be heard.

126. The Joint Committee of the States to Study Alcoholic Beverage Laws, Alcomolic Beverage Control 98-99 (1950).

127. $I d$. at 29 . 
Under either type of statute instances can arise in which two, or more, applicants apply for a single license. The procedural problem thus presented is whether the licensing agency can or should grant the license to one of the applicants without first giving the other an opportunity to be heard on the issue of comparative qualifications.

The various liquor control acts contain no explicit provisions concerning this question, and most administrators appear to ignore the problem. The majority of the agencies replying to the questionnaire either failed to answer the inquiry dealing with the subject or stated that the problem had not arisen in their state. A few answered specifically that comparative hearings were not given. ${ }^{128}$ Only Pennsylvania, Oregon and South Carolina indicated that comparative hearings are given to applicants for mutually exclusive licenses.

The one appellate decision involving the contention by a disappointed applicant for a mutually exclusive license that he should have been given a comparative hearing is the Connecticut case of Cusano v. Dunn. ${ }^{129}$ In that case, lessee operated a package store. There were sixteen other alcoholic beverage outlets within a radius of 1,500 feet of his place of business. Lessor, wishing to obtain possession of the premises so that his son, Cusano, might carry on an alcoholic beverage business, made it necessary for lessee to vacate the premises. Lessee thereupon acquired a nearby location and applied to the Connecticut Liquor Control Commission for a permit for the new location. Cusano notified the Commission that he would oppose lessee's application. The Chairman of the Commission put a note on lessee's file, "Hold for hearing on both applications." Notwithstanding, the Commission proceeded to hear and grant lessee's application. No appeal was taken from this action of the Commission. Thereafter the Commission denied Cusano's application on the ground that the number of like outlets in the vicinity made the granting of another permit detrimental to the public interest. Cusano appealed from this denial, contending that the applications were mutually exclusive and that the Commis-

128. Florida, Michigan, New York, Rhode Island.

129. 137 Conn. 20, 74 A.2d 477 (1950). See also City of Coral Gables v. State ex rel. Hassenteufel, 38 So.2d 467 (Fla. 1949) (city ordinance permitted only one license in the area; petitioner's license application was refused because another applicant had filed an application 24 hours earlier; petitioner filed a mandamus action against the city alleging that the other applicant was disqualified; the city answered that a license had already been isued to the other applicant; the lower court ordered the city to grant petitioner's application; the Supreme Court reversed holding that the city had not acted illegally or arbitrarily in granting the license to the other applicant and that because of the ordinance, issuance of one license "precluded the issuance of a license to" petitioner) ; Paron v. Shakopee, 226 Minn. 222, 32 N.W.2d 603, 2 A.L.R.2d 1227 (1948); Toppo License, 67 Pa. D. \& C. 101 (1948), both involving applications for mutually exclusive licenses but not presenting the issue of a right to comparative hearing. 
sion's failure to hear both applications together amounted to an abuse of discretion. Cusano relied upon the doctrine of Ashbacker Radio Corporation v. FCC ${ }^{\mathbf{1 3 0}}$ that where the statute provides that applications may not be denied without first giving the applicant an opportunity to be heard, the grant of one of two mutually exclusive applications without a hearing to both deprives the loser of the opportunity to be heard granted by statute. ${ }^{131}$ The Supreme Court of Errors of Connecticut rejected Cusano's argument, saying: "The granting of a certain radio frequency to one applicant precludes the physical feasibility of granting it to another. Permits to sell liquor in a given vicinity are not necessarily mutually exclusive either in fact or law. The granting of both permits was not physically impossible but rested within the discretion of the Commission." 132

The court's rejection of the Ashbacker doctrine on the ground that permits to sell liquor in a given vicinity are not necessarily mutually exclusive either in fact or in law is something less than satisfactory. It is true that the Connecticut Liquor Control Act merely authorizes, and does not require, the Commission to refuse an application "if the number of permits in the locality is such that the granting of the permit is detrimental to the public interest." 133 The Commission therefore undoubtedly had legal power to grant Cusano's application. It is true also that unlike the granting of a particular radio frequency, it was not physically impossible to grant both applications. But as the court itself pointed out, "The commission, whether the two applications were heard together or separately, was faced with the necessity of choosing between a new applicant at an old location and an existing permittee at a new location, unless the number of outlets in the neighborhood was to be increased." 134 The stated ground of the denial of Cusano's application was that the number of like outlets in the vicinity made the granting of another permit detrimental to the public interest. This is a clear indication that the Commission did not choose to increase the number of outlets. The Commission's determination not to increase the number of outlets thus in effect made the two applications mutually exclusive. ${ }^{135}$

The fact that the Connecticut court rejected the Ashbacker doctrine because of unsound reasoning does not mean that the doctrine

130. 326 U.S. 327 (1946).

131. The Connecticut Liquor Control Act provides that permits may be granted without a hearing but in case of denial of the application a hearing shall be given. Conn. Rev. Gen. Stat. § 4261 (1949).

132. 137 Conn. at 24,74 A.2d at 480 .

133. Conn. Rev. Gen. Stat. \$ 4263 (1949).

134. 137 Conn. at 22,74 A.2d at 479 . Italics added.

135. See Northwest Airlines v. CAA, 194 F.2d 339 (D.C. Cir. 1952). 
necessarily should or should not be applied in the field of alcoholic beverage licensing. It means simply that insofar as persuasive appellate precedent is concerned, the question is an open one.

Whether mutually exclusive alcoholic beverage license applications should be heard together should not depend upon what the $\mathrm{Su}$ preme Court of the United States did in a case involving the Federal Communications Commission. The problem should, instead, be solved primarily on the basis of whether in the particular situation presented a comparative hearing would be helpful or necessary in order to choose intelligently between the applicants. Thus if two mutually exclusive applications are filed practically simultaneously and if, after preliminary consideration of the applications and the staff's investigation reports, the agency is in doubt as to which application should be granted, a comparative hearing probably should be granted. But if the application or the investigation disclosed uncontrovertible disqualifying data concerning one of the applicants, such a hearing would perform no useful function. Or if a second application is filed while the agency is in the process of hearing the application filed first, undue delay might result were the agency to postpone the hearing until it investigated and prepared for a hearing on the second application. Or if a large number of applicants seeks a single license, consolidating the hearings might result in an unwieldy proceeding. In such a situation, an agency might reasonably conclude that it should hear the cases separately but defer final decision until all had been heard. In short, since the problem is the practical one of expeditious enlightenment of the agency, with due regard for the legitimate feelings of the persons involved, it should be solved on the practical, discretionary basis suggested, and not on any abstract basis that a comparative hearing always is or always is not appropriate or required.

(2) Competitors and Trade Associations. Only in Louisiana is there a statutory command that competitors be heard. ${ }^{136}$ A small group of the agencies replying to the questionnaire stated that existing licensees and trade associations are given an opportunity to be heard. ${ }^{137}$ Two allow individual licensees but not trade associations to be heard, not because they are licensees who will be competitively

136. LA. Rev. Stat. ANN. tit. 26, \$283.D (Supp. 1950) : In event "any trade organization consisting of brewers and distributors of beverages" containing not more than $6 \%$ alcohol by volume shall protest, a hearing shall be held. See also La. Acts 1952, No. 355 .

137. Connecticut, Illinois (existing licensees only), Michigan ("depending upon the issues involved, may participate by submittal of memoranda, and if necessary, participate in hearing."), Minnesota (existing licensees only), Oregon, Pennsylvania, Rhode Island. 
affected but because as ordinary protestants they may have an interest in opposing issuance. ${ }^{138}$

But one case, Hudson Bergen County Retail Liquor Stores Ass'n v. Hoboken, ${ }^{139}$ has been found in which an appellate court has ruled squarely on the right of competitors or a trade association of alcoholic beverage retailers to be heard in the issuance process. The Court of Errors and Appeals of New Jersey held that existing licensees, whether alone or through their trade association, were "aggrieved" persons entitled by statute to appeal to and be heard by the state Commissioner of Alcoholic Beverage Control. ${ }^{140}$ The sole issue in the de novo hearing before the state Commissioner was whether the local licensing board had abused its discretion by licensing an excessive number of otutlets. The New Jersey court stated that inasmuch as the purpose of the association was to regulate and control the alcoholic beverage traffic, the effort of the competitors and the association is in harmony with the objective of the New Jersey alcoholic beverage control statute. In such a case only a "slight private interest, added to and harmonizing with the public interest" will warrant an appeal to the Commissioner. Any pecuniary advantage that may result from limiting the number of licenses "is incidental to the major question of public morals and general welfare, and the possibility that appellant may reap some personal advantage from the result does not nullify the main quest." 141

Although the New Jersey decision is the only explicit appellate court ruling on the issue of whether competitors or trade associations are to be heard in the license issuance process, there are opinions of other courts suggesting a contrary view. ${ }^{142}$ Florida and Maryland have held that competitors have no standing to enjoin issuance or to secure a writ of mandamus to the licensing agency to cancel or revoke

138. California, Virginia. The Virginia reply noted that "Generally speaking, the objections of existing licensees are given very little weight in issuing a license." See also note 140 infra.

139. 135 N.J.L. 502, 52 A.2d 668 (1947). See also Hopkins v. Municipal Board of Alcoholic Beverage Control, 4 N.J. Super. 484, 67 A.2d 886 (1949) (existing licensee heard on issue of transfer of license to a location which allegedly would violate a municipal ordinance prohibiting establishment of new outlets within 750 feet of premises of existing licensee; question of competitor's right to be heard apparently not raised).

140. The New Jersey Acoholic Beverage Law provides that "any taxpayer or other aggrieved person opposing issuance of such license" may appeal to the state commissioner from the determination of the local licensing agency. N.J. STAT. ANN. $\$ 33: 1-22$ (Supp. 1951). The New Jersey questionnaire reply stated, "Existing licensees and trade associations are considered to be taxpayers or persons who may be aggrieved and, consequently, are entitled to participate as objectors."

141. 135 N.J.L. at 510, 52 A.2d at 673 (1947).

142. In appraising the significance of the New Jersey decision it should be noted: (1) the holding approved the decision of the Commissioner to hear the competitors; (2) failure to permit the competitors to appeal would have made the decision of the 
a license issued in violation of the licensing statute. ${ }^{143}$ Illinois and Maryland have ruled that a trade association of licensees has no standing in mandamus or injunction proceedings to challenge the action of the licensing agency. ${ }^{144}$ There are, of course, differences between standing to sue and opportunity to be heard. ${ }^{145}$ These decisions, therefore, do not necessarily determine that competitors or trade associations are not entitled to an opportunity to be heard. But they strongly suggest that courts will not require a licensing agency to give a hearing to competitors or trade associations. It is difficult to see how a court which holds that competitors do not have sufficient interest to institute a judicial challenge of allegedly erroneous administrative action could conclude that the competitors have such an interest as re-

local agency final, thus nullifying state authority in an important area of alcoholic beverage control; (3) the issue involved, one of excessive number of outlets, is a subject concerning which competitors are uniquely informed.

143. Baker v. State ex rel. Hi-Hat Liquors, Inc., $159 \mathrm{Fla} .286,31$ So.2d 275 (1947) (complainant licensee argued that the competitor's license had been issued in violation of the statute prohibiting outlets within 300 feet of a school site); Turner v. Miami, 160 Fla. 317, 34 So.2d 551 (1948) (complainant licensee argued that applicant's proposed place of business was less than the statutory 2500 feet from complainant's establishment); Baltimore Retail Liquor Package Stores Ass'n v. Kerngood, 171 Md. 426, 189 Atl. 209, 109 A.L.R. 1253 (1937) (competitors as individual licensees and as a trade association argued that legislation limiting to one the number of licenses to be granted to any corporation, but permitting corporations owning more than one retail drug store at the time of enactment of the statute to continue to be granted a license for each such drug store, did not permit the corporation to increase the number of its outlets by purchasing additional stores from licensed owners).

Cf. Romano v. Daneker, 73 A.2d 236 (R.I. 1950) (local agency approved application for licenses for premises within 200 feet of existing licensees' establishments; existing licensees' appeal to the state administrator was denied; the court affirmed; the question of competitors' right to be heard apparently was not raised); Frank v. Hub Liquors, Inc., 244 App. Div. 496, 279 N.Y. Supp. 636, aff'd, 268 N.Y. 688 (1935) ( $\$ 105.4$ of the New York Alcoholic Beverage Control Law prohibits the issuance of new licenses for premises within 1500 feet of previously licensed premises; $\$ 123$ authorizes the liquor authority or any taxpayer to petition for an order enjoining any person who shall traffic in alcoholic beverages "contrary to any provision of this chapter, or otherwise unlawfully"; pursuant to these provisions an existing licensee sought and secured an injunction against the second licensee and the members of the liquor authority; the question of the licensee's right to maintain the action apparently was not raised).

144. Retail Liquor Dealers Protective Ass'n v. Schreiber, 382 IIl. 454, 47 N.E.2d 462 (1943) (taxpayer and trade association argued that local licensing agency should be ordered to cancel licenses allegedly issued in violation of an ordinance prohibiting licensing of premises where any commodities other than alcoholic beverages were to be sold; held, association has no standing, but taxpayer as a citizen interested in enforcement of "public rights" may maintain the action); Retail Liquor Dealers Protective Ass'n v. Fleck, 408 I1l. 219, 96 N.E.2d 556 (1951) (association and persons granted licenses by local licensing agencies sought declaratory judgment and injunction that state commission could not refuse to issue licenses to persons licensed by local agencies; held, on authority of the Schreiber case that association has no standing); Baltimore Retail Liquor Package Stores Ass'n v. Kerngood, supra note 143 .

145. Standing to sue is primarily a judicial problem to be decided by the courts. In the absence of a constitutional issue or express or implied statutory requirements, third persons' opportunity to be heard is primarily an administrative problem to be decided by the agency. See also Davis, Administratrve Law 690 (1951). 
quires the agency to give them an opportunity to be heard concerning that action.

The problem of an opportunity to be heard by competitors and trade associations should not be troublesome to appellate courts. This is so because, first, these groups clearly have no constitutional right to be heard. Second, except in Louisiana where there is a specific statutory requirement, the conclusion that it was the purpose of the legislature that these groups be heard cannot be inferred from the alcoholic beverage control act viewed in its entirety. A statute directing the licensing agency to take into consideration the fact that the premises proposed to be licensed are within a specified distance of a particular institution, say a school, may properly be construed as giving the school the right to be heard with respect to an application for a location within the specified area. The statutory limitation is for the protection of the school; it is proper for the court to find a legislative purpose that the institution for whose benefit the statutory limitation was created should be heard. ${ }^{146}$ But legislation imposing requirements or limitations concerning newcomers to the alcoholic beverage business is not for the protection of existing licensees. It is for the protection and benefit of the public. There being no legislative purpose to protect existing licensees, they are not the persons for whose benefit the requirements or limitations were imposed. Therefore, unlike the school case, there is no sound reason for a court to conclude that it was the legislative purpose that existing licensees, either individually or as an association, should be afforded an opportunity to be heard.

There being neither a constitutional right nor an express or implied statutory requirement that existing licensees, either individually or as a group, be heard in the license issuance process, the issue becomes basically an administrative one of how the agency shall conduct its business. It is difficult to see how an appellate court could properly find reversible error whichever way the administrative agency resolved the issue. ${ }^{147}$

Except in one significant respect the considerations which should determine whether existing licensees shall be heard are basically the same as those which should govern the nature of participation by ordinary protestants. The difference between competitors and ordinary protestants is that there is little danger that the latter, either individually or in groups, will exercise an improper influence on the licensing agency. The same cannot be said of existing licensees, especially of

146. Azarewicz Liquor License Case, 163 Pa. Super. 459, 62 A.2d 78 (1948).

147. But see Moretti v. Divison of Intoxicating Beverages, 62 R.I. 281,5 A.2d 288 (1939), note 124 supra. 
organized associations of licensees. One of the weaknesses of the administrative process is that administrative agencies only too often align themselves more with the interests they regulate than with the public interest they were established to protect. ${ }^{148}$ The history of alcoholic beverage control before the Eighteenth Amendment amply demonstrates the dangers of industry control of the licensing agency. ${ }^{149}$ This danger will exist whether or not existing licensees are heard in the issuance process. But to permit such licensees to be heard would provide an additional opportunity for industry to urge its views on the agency and to exercise a subtle influence. Weighing the assistance to be gained from existing licensees against the danger of undue influence by those licensees, I conclude that rarely if at all should existing licensees be heard in the license issuance process. ${ }^{150}$

\section{ConcLuston}

The most striking fact which emerges from this study of legislative, administrative, and judicial requirements and practices in the issuance of state alcoholic beverage licenses is the extent to which license applicants are afforded an opportunity to be heard. Particularly noteworthy is the position taken by many administrators, whose statutes do not require it, that applicants should be heard before being refused the "privilege" of engaging in the business of their choice. That administrative officials under no constitutional or statutory compulsion to do so should, as a matter of policy, elect to hear license applicants is a highly encouraging departure from the supposed tendency of many state administrative agencies to conclude that so long as their procedures satisfy the minimum demands of due process the procedures are unobjectionable.

The rather widespread practice in alcoholic beverage license issuance proceedings to give hearings although not required to do so strongly suggests that "bureaucrats" are not always as arbitrary and despotic as they are sometimes pictured. In the field covered by this study, at least, quite the opposite appears to be true. Except for the few agencies which unwisely cling to the view that alcoholic beverage licenses are "privileges" which may be denied without a hearing, a fair criticism is not that applicants are arbitrarily denied an opportunity to be heard but that hearings are given in some instances in

148. See note 119 supra; and see Davis, Administrative Law 164 (1951).

149. See note 120 supra; and see Fosprck and Scotr, Toward Liquor Control. 41 (1933).

150. One such rare instance may be the case where a local determination will stand unless competitors are permitted to appeal to the state agency. See text at note 124 supra; see also note 142 supra. 
which they are unnecessary. Legislatures and agencies should recognize that there is no necessity for either granting hearings to all applicants or denying hearings to all applicants. The selective process of agency definition of those classes of cases in which a hearing will not be given because it would serve no useful purpose would be vastly superior to the either-or approach currently followed by most legislatures and administrative agencies.

A graver procedural defect-and again not because it trenches on legitimate private interest but because it involves wasteful expenditure of community resources-is the requirement of a few states for de novo judicial review of license issuance determinations. This procedure of making courts super-licensing agencies-especially where the administrative agency has made its determination after a hearing -results in expensive duplication of governmental activity, diffuses responsibility, hinders uniform application of the standards of the licensing statute, and tends to put the judiciary into politics. Fortunately some courts, sensing the undesirable consequences which would flow from literal interpretation of de novo review provisions, have refused to exercise an independent judgment as to the propriety of the administrative action. Although this commendable self-restraint makes de novo review provisions less objectionable than they otherwise would have been, they are still basically unsound. It is difficult to see any legitimate reason for their continuance.

On the judicial balance sheet, the entry resulting from the judiciary's enlightened treatment of de novo court review provisions is more than offset by the general judicial agreement with the conclusion of those few licensing agencies which decided that, since the statute neither expressly required nor prohibited hearings, applications might be refused without a hearing. Although it probably is true that due process does not require a hearing in alcoholic beverage issuance proceedings, a court should not passively acquiesce in administrative denials of hearings. If the refusal to issue a license is based upon intangibles like present reputation or upon controverted facts relating to past events, the method of a trial is an unusually effective means for resolving the issue. In such a case, a hearing should not be dispensed with unless there are weighty reasons for such a dispensation. The judiciary's failure to insist upon proof of such factors is an unfortunate abdication of judicial responsibility.

The extent and character of third-person participation presents the most troublesome aspect of the opportunity to be heard in the issuance of alcoholic beverage licenses. This is so because two conflicting considerations compete for supremacy. First is the proposi- 
tion emphasized by many administrators that granting third persons an opportunity to be heard will tend to bring out all the relevant facts and thus enable the agency to reach an informed judgment in the public interest. Against this is the argument that there is no need to complicate and delay the hearing process with third-person participation because the objective of full information can be achieved by permitting protestants to invite attention of the agency's staff to disqualifying characteristics and because the staff can be relied upon to develop all legitimate leads.

Although the second argument is logical and appealing, there should be no criticism of any agency which concludes that its staff will not or cannot adduce relevant data as well as, or unless assisted by, ordinary protestants. The agency is the best judge of its staff's capacities. Granting ordinary protestants an opportunity to be heard will in many instances perform the important political function of satisfying the legitimate feelings of those persons that as individuals affected by the agency's decision they should be permitted to participate to the fullest in seeing to it that there is complete compliance with the restrictive requirements of the applicable control act. Encouraging adversary, ordinary protestant participation in the hearing will tend to counteract political or other improper influences in license issuance. Because of the demonstrated danger of industry control of licensing agencies, however, participation by existing licensees should be rigidly limited.

Finally, this study provides additional documentation, if any be needed, for the conclusion of the Attorney General's Committee and Commissioner Benjamin that diversity rather than uniformity characterizes administrative procedures. Even in the narrow field of issuing alcoholic beverage licenses to retailers there are diversities among the states and within a single state. Here, as elsewhere, practical needs, not doctrinaire uniformity, should be and are the controlling criteria. 


\section{APPENDIX}

\section{Questionnaire Re Opportunity to be Heard in tee Issuance of State RetaIl Alcoholic Beverage Licenses}

[The terms "hearing" and opportunity to be "heard" mean a procedure akin to a trial in court, i.e., a "quasi-judicial" type hearing with a right to introduce evidence, cross-examine, etc.]

I. Does your agency give a "hearing" to applicants for retail alcoholic beverage licenses-
A. On all applications?
B. In event the application is initially refused without a hearing and the applicant thereafter requests a hearing?
C. In event third persons protest issuance of the license? Is the "third person" category limited to specified groups, e.g., churches, schools, etc. - or does it include protestants of every character?
D. On appeal to your agency from an adverse determination by a local licensing agency?
E. In other situations? If so, please specify.
F. In no case?

II. If a hearing is required in any of the situations listed in question I, is the requirement imposed by-
A. Statute?
B. Administrative rule or regulation?
C. Administrative policy not expressed in a formal rule or regulation?

III. If a hearing is required in any of the situations listed in question $I$ and the requirement is not imposed by statute, what are the reasons which induced your agency to grant the hearing?
A. Is it because hearings are needed in deciding some particularly difficult factual questions but not in other situations? E.g., the determination of an applicant's "good character" may be appropriate for a hearing procedure, but when the question is whether the applicant has been convicted of a crime within a stated period, a hearing is not needed.
B. Is it because your statute requires public notice of the application, from which requirement it may be inferred that the legislature in- tended a hearing in event of protest?
C. Is it because in providing for judicial review the legislature referred to the "record" of the administrative proceeding, from which it may be inferred that the legislature intended a hearing in the issuance process?
D. Is it because you think it only "fair" that an applicant be heard?
E. If there are other reasons, please specify.

IV. If your agency does not grant hearings in the process of issuing retail alcoholic beverage licenses, what are the reasons which induced your agency not to grant hearings?

A. Is it because your statute requires a hearing in suspension or revocation cases but not in issuance cases, from which it may be inferred that the legislature did not intend that a hearing be given in issuance cases?

B. Is it because, although hearings might be desirable in issuance cases, personnel limitations make it difficult or impossible both to give hearings in such cases and also to discharge your other responsibilities?

C. Is it because hearings are unnecessary in light of the opportunities afforded applicant to supply information and meet objections in what may be called the informal administrative process-filling-in application forms, interviews, conferences, letters, etc.?

$D$. Is it because hearings are unnecessary in light of the thorough investigation conducted by the licensing or investigative section of your staff?

E. Is it because there is a de novo court review? 
F. Is it because although court review is not de novo, the court's power to correct "unreasonable" or "arbitrary" action provides sufficient protection to applicants?

G. If there are other reasons, please specify.

V. What procedures, if any, short of a hearing are employed by your agency to inform the applicant of deficiencies in his application or of objections to issuance raised by your staff or third persons?

VI. What procedures, if any, short of a hearing are employed by your agency to enable the applicant to correct deficiencies in his application or to meet objections to issuance raised by your staff or third persons?

VII. If the liquor control act of your state requires a hearing on all applications, or on all applications of a certain type, e.g., applications for beer licenses, would you agree or disagree with the following explanation of the probable reason for such a requirement?

"All of the liquor control acts which require hearings on all applications for certain types of retail licenses are found in states which provide for some degree of local participation in the license issuance process, and the hearings required are, with one exception, to be held before the local licensing agency. This coincidence of local participation and insistence upon a hearing on all applications suggests the possibility that the purpose of the hearing requirement is not so much for the benefit of the applicant as it is to give members of the local public an opportunity to present information or objections concerning the applicant."

VIII. If your state is one of those whose statute requires a hearing on all applications or on all applications of a certain type, what is the type of hearing granted, and which class-applicant or protestant-is the primary beneficiary of the requirement? There are at least the following possibilities :

A. The hearing is a full trial-type hearing primarily for the benefit of the applicant, with protestants participating-

1. As parties with full rights to introduce evidence, cross-examine, etc., or

2. In a limited fashion with only the right to present written or oral statements of objection to issuance.

$B$. The hearing is a quasi-legislative or public meeting type of hearing given primarily so that protestants can record their written or oral objections to issuance.

IX. If your agency is one of those which gives a hearing in the event that after the application has been refused, the applicant requests a hearing, are statistics or other data available as to the number and/or percentage of applicants who avail themselves of the opportunity to be heard?

A. In notifying the applicant that his application has been refused, does your agency state the reasons for the refusal? In how much detail?

$B$. Is there any relation between the stated reasons for refusal and the likelihood that the applicant will request a hearing? In other words, is it more likely that an applicant will not request a hearing when the agency reason for refusal is of an uncontrovertible and easily ascertainable character-e.g., conviction of a crime-than if the reason is one which is more general and subject to challenge in a hearinge.g., lack of "good character"?

$\mathrm{X}$. If your agency is one of those which gives a hearing on appeal to the agency from an adverse determination by a local license agency-

A. Do the local agencies give hearings?

B. What is the scope of your agency's review of the local decisioncompletely independent or limited to ascertaining whether the local decision is unsupported by substantial evidence, is unreasonable, arbitrary, etc.?

C. Does your agency decide the appeal on the basis of the record of the proceedings before the local agency or does it conduct a de novo hearing? 
XI. If your agency is one of those which gives protestants an opportunity to participate in the license issuance process-

A. Do you do so because of statutory requirements, or as a matter of administrative policy? If the latter, what are the reasons for affording such participation?

B. What is the character of the participation? Is the protestant entitled to introduce evidence, cross-examine, etc. or is his participation limited to submitting oral or written objections?

C. What in your opinion accounts for the provisions in some statutes that even a single "protestant," "citizen," "resident," "person," or "taxpayer" shall be heard in the license issuance process?

D. Do you think that as a matter of policy the persons mentioned in part $C$ of this question should be entitled to full participation with the right to introduce evidence, cross-examine, etc., or should they be limited to filing written or oral statements? Why?

XII. If your statute provides for public notice or advertisement of the application-

A. Does this in your opinion mean that the legislature intended that members of the public to whom the notice is addressed are entitled to be heard on the matter, or

B. Does such a provision mean merely that members of the public are entitled to make known their objections in a less formal fashion than full participation in a hearing on the application?

XIII. If two or more applicants seek a license, and either because of statutory quota limitations or as a matter of administrative policy the applications are in fact mutually exclusive, does your agency give the applicants a comparative hearing or permit the subsequent applicant to intervene in the hearing on the prior application? If so, why? If not, why not?

XIV. Does your agency permit existing licensees or trade associations of licensees to participate in the license issuance process?

A. If so, what is the character of the participation-full hearing or mere submittal of memoranda etc.?

B. If not, why not?

$\mathrm{XV}$. Are there any phases of this general topic not covered by this questionnaire which your agency has found troublesome? If so, please specify. 